\title{
Labile $\mathrm{Fe}(\mathrm{II})$ concentrations in the Atlantic sector of the Southern Ocean along a transect from the subtropical domain to the Weddell Sea Gyre
}

\author{
G. Sarthou ${ }^{1,2}$, E. Bucciarelli ${ }^{1,2}$, F. Chever ${ }^{1,2}$, S. P. Hansard ${ }^{3}$, M. González-Dávila ${ }^{4}$, J. M. Santana-Casiano ${ }^{4}$, \\ F. Planchon ${ }^{1,2}$, and S. Speich ${ }^{1,5}$ \\ ${ }^{1}$ Université Européenne de Bretagne, Brest, France \\ ${ }^{2}$ CNRS, Université de Brest, IRD, UMR6539 LEMAR, IUEM; Technopôle Brest Iroise, Place Nicolas Copernic, \\ 29280 Plouzané, France \\ ${ }^{3}$ Florida Geological Survey, 903 W. Tennessee Street, Tallahassee FL 32301, USA \\ ${ }^{4}$ Facultad de Ciencias del Mar. Departamento de Quimica, Universidad de Las Palmas de Gran Canaria, \\ Campus de Tafira, 35017, Las Palmas de Gran Canaria, Spain \\ ${ }^{5}$ Université de Brest, CNRS, IRD, IFREMER, UMR6523 LPO, IUEM; 6, avenue Le Gorgeu, 29238 Brest, France
}

Received: 1 April 2011 - Published in Biogeosciences Discuss.: 29 April 2011

Revised: 5 August 2011 - Accepted: 22 August 2011 - Published: 6 September 2011

\begin{abstract}
Labile Fe(II) distributions were investigated in the Sub-Tropical South Atlantic and the Southern Ocean during the BONUS-GoodHope cruise from 34 to $57^{\circ} \mathrm{S}$ (FebruaryMarch 2008). Concentrations ranged from below the detection limit $(0.009 \mathrm{nM})$ to values as high as $0.125 \mathrm{nM}$. In the surface mixed layer, labile $\mathrm{Fe}(\mathrm{II})$ concentrations were always higher than the detection limit, with values higher than $0.060 \mathrm{nM}$ south of $47^{\circ} \mathrm{S}$, representing between $39 \%$ and $63 \%$ of dissolved $\mathrm{Fe}(\mathrm{DFe})$. Apparent biological production of $\mathrm{Fe}$ (II) was evidenced. At intermediate depth, local maxima were observed, with the highest values in the SubTropical domain at around $200 \mathrm{~m}$, and represented more than $70 \%$ of DFe. Remineralization processes were likely responsible for those sub-surface maxima. Below $1500 \mathrm{~m}$, concentrations were close to or below the detection limit, except at two stations (at the vicinity of the Agulhas ridge and in the north of the Weddell Sea Gyre) where values remained as high as $\sim 0.030-0.050 \mathrm{nM}$. Hydrothermal or sediment inputs may provide $\mathrm{Fe}(\mathrm{II})$ to these deep waters. $\mathrm{Fe}$ (II) half life times $\left(t_{1 / 2}\right)$ at $4{ }^{\circ} \mathrm{C}$ were measured in the upper and deep waters and ranged from 2.9 to $11.3 \mathrm{~min}$, and from 10.0 to $72.3 \mathrm{~min}$, respectively. Measured values compared quite well in the upper waters with theoretical values from two published models, but not in the deep waters. This may be due to the lack of
\end{abstract}

Correspondence to: G. Sarthou (geraldine.sarthou@univ-brest.fr) knowledge for some parameters in the models and/or to organic complexation of $\mathrm{Fe}(\mathrm{II})$ that impact its oxidation rates. This study helped to considerably increase the Fe(II) data set in the Ocean and to better understand the Fe redox cycle.

\section{Introduction}

Iron $(\mathrm{Fe})$ is an essential micronutrient for all marine organisms, playing a key role in many metabolic processes, such as photosynthesis, respiration, nitrate reduction, and nitrogen fixation (Sunda, 1988-1989). Its low concentrations have been suggested to limit primary production in more than $50 \%$ of the ocean (Boyd and Ellwood, 2010). All natural and artificial Fe fertilization experiments have unequivocally showed the importance of Fe for the carbon cycle, particularly for the growth and composition of the phytoplanktonic community (Boyd et al., 2000; Coale et al., 1996, 2004; Gervais et al., 2002; Tsuda et al., 2003; Boyd, 2004; Blain et al., 2007; Pollard et al., 2007). Despite numerous studies on Fe cycling over the last 25 years, many unknowns persist, in particular because $\mathrm{Fe}$ chemistry in seawater is very complex. Fe has been observed to occur in two redox states (Fe(III) and $\mathrm{Fe}(\mathrm{II})$, Waite and Morel, 1984). In oxic seawater, the thermodynamically most stable state is $\mathrm{Fe}(\mathrm{III})$, but is highly insoluble $(0.011 \mathrm{nM}$ in $0.7 \mathrm{NaCl}$ solution, Liu and Millero, 2002) and is rapidly hydrolyzed resulting in the

Published by Copernicus Publications on behalf of the European Geosciences Union. 
formation of various $\mathrm{Fe}$ (III) oxyhydroxide (de Baar and de Jong, 2001). These species, with $\mathrm{Fe}(\mathrm{OH})_{3}$ being the dominant one in seawater at $\mathrm{pH} \sim 8$, have the tendency to form colloidal Fe (Kuma et al., 1996) which coagulate and form particulate Fe (Johnson et al., 1997). In contrast to Fe(III), $\mathrm{Fe}(\mathrm{II})$ is more soluble but is rapidly oxidized by oxygen $\left(\mathrm{O}_{2}\right)$ and hydrogen peroxide $\left(\mathrm{H}_{2} \mathrm{O}_{2}\right)$ (Millero et al., 1987; Millero and Sotolongo, 1989; Santana-Casiano et al., 2004, 2005; González-Dávila et al., 2005, 2006). Although Fe(II) in seawater is less stable than Fe(III), recent models of Fe acquisition by eukaryotic phytoplankton suggest that the reduction of $\mathrm{Fe}(\mathrm{III})$ to $\mathrm{Fe}(\mathrm{II})$, with subsequent re-oxidation to $\mathrm{Fe}(\mathrm{III})$, is a possible mechanism by which $\mathrm{Fe}$ is made more bioavailable to phytoplankton (Shaked et al., 2004; Salmon et al., 2006; Maldonado et al., 2006; Morel et al., 2008). Numerous studies have investigated the oxidation of $\mathrm{Fe}(\mathrm{II})$ by $\mathrm{O}_{2}$ and $\mathrm{H}_{2} \mathrm{O}_{2}$ in different aqueous solutions to understand the behavior of $\mathrm{Fe}$ (II) in natural waters (Santana-Casiano et al., 2006 and references herein). The most widely accepted mechanism to describe $\mathrm{Fe}$ oxidation with $\mathrm{O}_{2}$ and $\mathrm{H}_{2} \mathrm{O}_{2}$ is the Haber-Weiss mechanism, with reactions 1 or 3 limiting the overall oxidation rate (King et al., 1995).

$\mathrm{Fe}(\mathrm{II})+\mathrm{O}_{2} \rightarrow \mathrm{Fe}(\mathrm{III})+\mathrm{O}_{2}^{\bullet-}$

$2 \mathrm{H}^{+}+\mathrm{Fe}(\mathrm{II})+\mathrm{O}_{2}^{\bullet-} \rightarrow \mathrm{Fe}(\mathrm{III})+\mathrm{H}_{2} \mathrm{O}_{2}$

$\mathrm{Fe}(\mathrm{II})+\mathrm{H}_{2} \mathrm{O}_{2} \rightarrow \mathrm{Fe}(\mathrm{III})+\mathrm{OH}^{-}+\mathrm{HO}^{\bullet}$

$\mathrm{Fe}(\mathrm{II})+\mathrm{HO}^{\bullet} \rightarrow \mathrm{Fe}(\mathrm{III})+\mathrm{OH}^{-}$

The rates for Eq. (1-4) strongly depend on the relative concentrations of the individual $\mathrm{Fe}(\mathrm{II})$ species in solution, mainly $\mathrm{Fe}^{2+}, \mathrm{Fe}(\mathrm{OH})^{+}, \mathrm{Fe}(\mathrm{OH})_{2}, \mathrm{FeHCO}_{3}^{+}, \mathrm{Fe}\left(\mathrm{CO}_{3}\right)_{2}^{2-}$, and $\mathrm{FeCO}_{3}\left(\mathrm{OH}^{-}\right)$(Millero, 1989; King, 1998; SantanaCasiano et al., 2006; Trapp and Millero, 2007), as well as on the concentrations of $\mathrm{O}_{2}$ and $\mathrm{H}_{2} \mathrm{O}_{2}, \mathrm{pH}$, temperature $(T)$ and salinity $(S)$. In warm oxygenated seawater, the half-life of Fe(II) can be as low as few seconds (King, 1998), whereas in cold surface or suboxic waters it can be on the order of hours to days (Croot et al., 2001; Croot et al., 2008; Hansard et al., 2009, Moffett et al., 2007).

Several mechanisms provide Fe(II) in the dissolved phase and are reviewed by Hansard et al. (2009). They consist of in situ processes (both abiotic and biotic) and external sources. The abiotic in situ processes are mainly photochemical reactions. They include photoreduction of dissolved $\mathrm{Fe}$ (III) (oxy)hydroxides and photoreduction or photolysis of organic, colloidal and particulate Fe (Rich and Morel, 1990; Wells et al., 1991; Kuma et al., 1992a, b; King et al., 1993; Barbeau et al., 2001; Rijkenberg et al., 2006). Extracellular reduction of $\mathrm{Fe}$ (III) by photochemically-produced superoxide or reductive dissolution of particulate $\mathrm{Fe}(\mathrm{III})$ may also occur (Voelker and Sedlak, 1995; Rose and Waite, 2002, 2003, 2005; Kustka et al., 2005; Salmon et al., 2006). Biotic in situ processes include bioreduction of organic $\mathrm{Fe}(\mathrm{III})$ at cell surface (Maldonado and Price, 1999, 2001; Shaked et al., 2004; Morel et al., 2008), reduction by biogenic superoxide (Rose and Waite, 2002, 2003; Salmon et al., 2006), as well as remineralization via microbial activity (Alldredge and Cohen, 1987), cell lysis (Gobler et al., 2002), and grazing (Hutchins and Bruland, 1994; Hutchins et al., 1995; Sarthou et al., 2008). The external sources are atmospheric inputs (Kieber et al., 2001; Journet et al., 2007; Ozsoy and Saydam, 2001), sediment inputs (Elrod et al., 2004; Lohan and Bruland, 2008), submarine groundwater discharge (Windom et al., 2006), and hydrothermal vents (Coale et al., 1991; Chin et al., 1994; Field and Sherrell, 2000; Statham et al., 2005; Bennett et al., 2008). These sources supply Fe(II), which can then be transported by advective and/or diffusive mixing.

Although it is now evident that $\mathrm{Fe}(\mathrm{II})$ plays a key role in Fe chemistry and bioavailability in the ocean, there are relatively few open-ocean measurements of $\mathrm{Fe}$ (II) available due to the difficulty of measuring such an ephemeral species at subnanomolar concentrations (Bruland and Rue, 2001). To our knowledge, the most comprehensive data set of Fe(II) was published by Hansard et al. (2009) in the Pacific Ocean along a zonal transect at $30^{\circ} \mathrm{N}$ and a meridional one at $152^{\circ} \mathrm{W}$, within the CLIVAR/CO 2 Repeat Hydrography Program. In this paper, we present results of the Bonus-GoodHope (BGH) cruise, carried out in FebruaryMarch 2008 during the International Polar Year in the SubTropical South Atlantic and the Southern Ocean. Fe(II) distributions as well as oxidation rates are presented and results are discussed considering different production processes, including: photoreduction, oxidation, biological production, and different inputs, such atmospheric, sediment, and hydrothermal inputs, and/or advection and mixing.

\section{Materials and methods}

\subsection{Study area}

Sampling and shipboard measurements were done aboard R/V Marion Dufresne from 8 February to 24 March 2008 in the Atlantic sector of the Southern Ocean during the BGH cruise. Figure 1 shows the cruise track together with the main oceanographic fronts and domains crossed during the cruise, from north to south: (i) the subtropical domain and the southern subtropical front (S-STF), (ii) the Antarctic Circumpolar Current (ACC) domain with 3 fronts crossed, the subantarctic front (SAF), the polar front (PF) and the southern ACC front (SACCF), and (iii) the eastern part of the Weddell Sea gyre with the southern boundary (SBdy) separating this domain from the ACC. Twelve stations were sampled for Fe(II), among which seven were sampled between 0 and $2000 \mathrm{~m}$ (Large stations L1 to L7) and five between 0 to $4000 \mathrm{~m}$ (Super stations $\mathrm{S} 1$ to S5). The position of each station is reported in Fig. 1 and Table 1. 


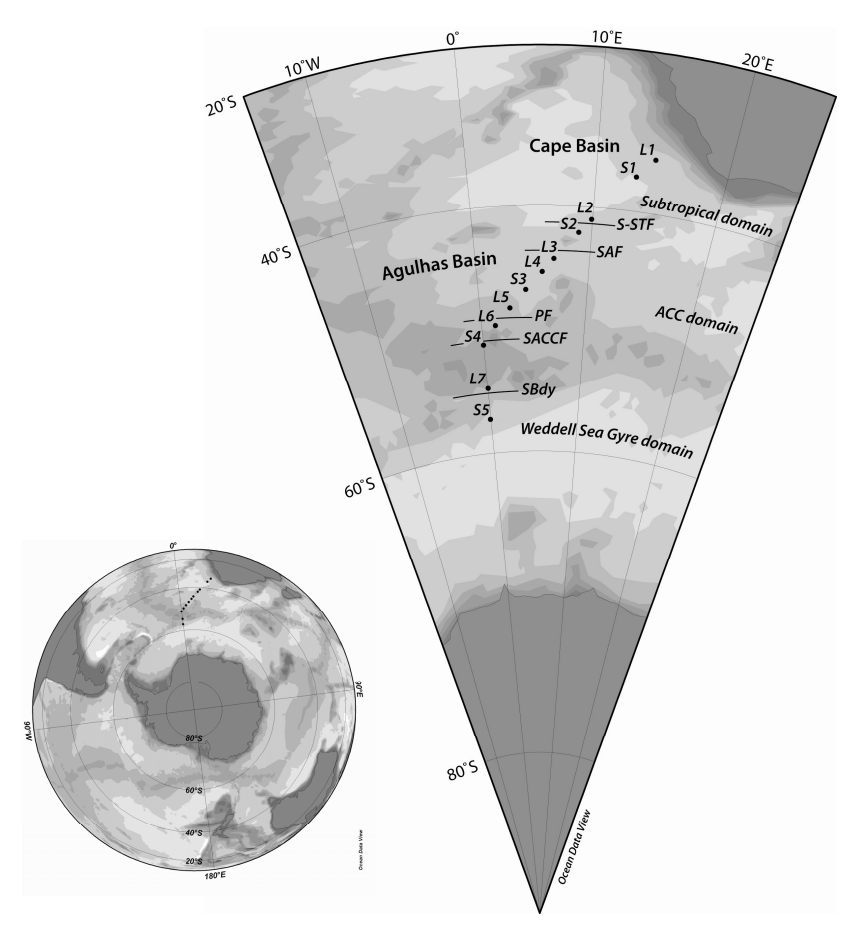

Fig. 1. Location of the stations sampled during the BONUSGoodHope cruise along with the three main oceanographic provinces encountered (a larger scale of the studied area is given in the inset map). The three domains crossed were the subtropical domain (stations L1, S1 and L2), the ACC domain (stations S2, L3, L4, S3, L5, L6, S4 and L7) and the eastern part of the Weddell Sea Gyre (station S5). Five fronts were crossed: the southernsubtropical front (S-STF), the sub Antarctic front (SAF), the polar front (PF), the southern ACC front (SACCF) and the southern boundary (Sbdy).

\subsection{Sample processing and analytical methods}

Samples were collected using acid-cleaned $12 \mathrm{~L}$ Go-Flo bottles. When not in use, the Go-Flo bottles were stored inside a clean van with plastic bags covering the top and the bottom including the spigots. On station, the Go-Flo bottles were transferred to the sampling deck and mounted on a Kevlar cable. Plastic bags were removed just after attachment to the Kevlar cable. When the expected depths were reached, bottles were tripped by a Teflon ${ }^{\circledR}$ messenger. Once back on board, the bottles were directly transferred to the clean van for sub-sampling. All sub-samples for Fe(II) measurements were immediately collected in previously $60 \mathrm{~mL}$ acidcleaned high density brown polyethylene (HDPE) bottles. The maximum time between sub-sampling time from the GoFlo bottle and analysis was $3 \mathrm{~min}$. In order to minimize this time, no filtration was carried out, thus avoiding an underestimation of $\mathrm{Fe}$ (II) concentrations due to rapid oxidation. However, $\mathrm{Fe}$ (II) produced by fast-kinetic processes involving lithogenic or biogenic particles, such as reductive dissolution of particulate Fe(III) (Rich and Morel, 1990) or bioreduc- tion of organic $\mathrm{Fe}(\mathrm{III})$ at cell surface (Maldonado and Price, 1999, 2001; Shaked et al., 2004; Morel et al., 2008) is measured and tends to overestimate Fe(II) concentrations. On the other hand, the filtration step may cause some artifacts. First, damage and explosion of the cells may cause release of $\mathrm{Fe}(\mathrm{II})$ (Hutchins et al., 1993). Second, filtration-induced cell stress can increase the production of superoxide (Godrant et al., 2009). This reactive oxygen species is involved in the redox $\mathrm{Fe}$ cycle, but it also initiates the three-step oxidation of luminol (Ussher et al., 2005; Rose and Waite, 2001), thus potentially inducing an overestimation of the $\mathrm{Fe}(\mathrm{II})$ concentrations in the dissolved phase. In the following, the term "labile" Fe(II) is then used, since the measurement is operationally defined and the exact speciation of the measured fraction is not known (Ussher et al., 2007).

Labile Fe(II) concentrations were determined by chemiluminescence flow injection analyses following the method of King et al (1995) adapted by Croot and Laan (2002). As in Croot and Laan (2002), there was no preconcentration prior to reaction with luminol, allowing a minimal analytical time ( $\sim 80-90$ s). The percentage of labile Fe(II) was calculated as the ratio of labile $\mathrm{Fe}$ (II) over the dissolved $\mathrm{Fe}$ concentration (i.e. $(\mathrm{Fe}(\mathrm{II}) / \mathrm{DFe}) * 100)$. The instrument was calibrated by standard addition using peak height measurements and freshly prepared acidified Fe(II) standards added to a surface (20-300 m) and a deep (300-2000 m) sample. Samples were stored at $4{ }^{\circ} \mathrm{C}$ in the dark for $24 \mathrm{~h}$ to enable complete decay of ambient $\mathrm{Fe}(\mathrm{II})$. Non-linear calibration curves were observed, due to the kinetics of luminol oxidation and free-radical generation (Rose and Waite, 2001), and a polynomial 2nd degree curve-fitting technique was used to quantify the results. The blank was determined daily by running an aged seawater sample $\left(4^{\circ} \mathrm{C}\right.$ for $\left.24 \mathrm{~h}\right)$. It ranged from 0.014 to $0.072 \mathrm{nM}$ with a mean value of $0.036 \pm 0.012 \mathrm{nM}(n=29)$. The detection limit calculated as three times the standard deviation of the blank, ranged from 0.001 to $0.028 \mathrm{nM}$ with a mean value of $0.009 \pm 0.006 \mathrm{nM}(n=29)$.

After each $\mathrm{Fe}(\mathrm{II})$ spike, the change in $\mathrm{Fe}(\mathrm{II})$ signal was recorded over $10 \mathrm{~min}$ at $80-90 \mathrm{~s}$ intervals, and allowed us to estimate $\mathrm{Fe}(\mathrm{II})$ oxidation rates, similar to Roy et al. (2008). The oxidation rates may be overestimated by up to $\sim 10 \%$ due to $\mathrm{pH}$ decrease after standard addition $(\sim 0.1 \mathrm{pH}$ unit/standard addition). In addition to the samples used for the calibrations, for the four super stations S2 to S5, analyses were also performed with deeper samples (2300-3600 m).

\subsection{Ancillary measurements}

In addition to $\mathrm{Fe}(\mathrm{II})$, samples for dissolved $\mathrm{Fe}$ $(\mathrm{Fe}(\mathrm{III})+\mathrm{Fe}(\mathrm{II}), \quad \mathrm{DFe})$ and hydrogen peroxide $\left(\mathrm{H}_{2} \mathrm{O}_{2}\right)$ analyses were collected from the same Go-Flo bottles. DFe samples were collected in acid-washed low density polyethylene (LDPE) and $\mathrm{H}_{2} \mathrm{O}_{2}$ samples were collected in high density brown polyethylene (HDPE) bottles. DFe concentrations were determined by FIA with in-line 
Table 1. Location of the stations sampled during the cruise in relation to the domains and fronts crossed. Mixed layer depth observed from the vertical profile of temperature for nearby CTD station, as well as day and time of sampling are indicated. Dates are in DD/MM/YYYY format $(\mathrm{D}=$ day, $\mathrm{M}=$ month and $\mathrm{Y}=$ year).

\begin{tabular}{|c|c|c|c|c|c|c|}
\hline $\begin{array}{l}\text { Oceanographic } \\
\text { Domain }\end{array}$ & $\begin{array}{l}\text { Fronts } \\
\text { crossed }\end{array}$ & Station & Position & $\operatorname{MLD}(\mathrm{m})$ & $\begin{array}{r}\text { Day of } \\
\text { sampling }\end{array}$ & $\begin{array}{r}\text { Time of } \\
\text { sampling }\end{array}$ \\
\hline \multirow[t]{4}{*}{ Subtropical } & & L1 & $34.43^{\circ} \mathrm{S}, 14.40^{\circ} \mathrm{E}$ & $50-60$ & $17 / 02 / 2008$ & $10: 50$ \\
\hline & & S1 & $36.50^{\circ} \mathrm{S}, 13.10^{\circ} \mathrm{E}$ & $40-50$ & $20 / 02 / 2008$ & $00: 15$ \\
\hline & & L2 & $41.18^{\circ} \mathrm{S}, 09.92^{\circ} \mathrm{E}$ & 25 & $25 / 02 / 2008$ & $23: 15$ \\
\hline & S-STF & & $42.2^{\circ} \mathrm{S}$ & & & \\
\hline \multirow[t]{12}{*}{ ACC } & & S2 & $42.47^{\circ} \mathrm{S}, 08.93^{\circ} \mathrm{E}$ & $50-80$ & $27 / 02 / 2008$ & $18: 30$ \\
\hline & SAF & & $44.2^{\circ} \mathrm{S}$ & & & \\
\hline & & L3 & $44.88^{\circ} \mathrm{S}, 06.88^{\circ} \mathrm{E}$ & $60-80$ & $01 / 03 / 2008$ & $17: 45$ \\
\hline & & L4 & $46.02^{\circ} \mathrm{S}, 05.87^{\circ} \mathrm{E}$ & 80 & 03/03/2008 & $05: 40$ \\
\hline & & S3 & $47.55^{\circ} \mathrm{S}, 04.37^{\circ} \mathrm{E}$ & $80-100$ & 05/03/2008 & $15: 50$ \\
\hline & & L5 & $49.03^{\circ} \mathrm{S}, 02.84^{\circ} \mathrm{E}$ & $100-110$ & 07/03/2008 & $16: 30$ \\
\hline & $\mathrm{PF}$ & & $50.2^{\circ} \mathrm{S}$ & & & \\
\hline & & L6 & $50.38^{\circ} \mathrm{S}, 01.33^{\circ} \mathrm{E}$ & $60-80$ & 09/03/2008 & 04:05 \\
\hline & SACCF & & $51.5^{\circ} \mathrm{S}$ & & & \\
\hline & & S4 & $51.85^{\circ} \mathrm{S}, 00.00^{\circ} \mathrm{E}$ & $120-150$ & $10 / 03 / 2008$ & $12: 10$ \\
\hline & & L7 & $55.23^{\circ} \mathrm{S}, 00.03^{\circ} \mathrm{E}$ & $80-110$ & $13 / 03 / 2008$ & $22: 30$ \\
\hline & Sbdy & & $55.5^{\circ} \mathrm{S}$ & & & \\
\hline $\begin{array}{l}\text { Eastern part of the } \\
\text { Weddell Sea Gyre (EWSG) }\end{array}$ & & S5 & $57.55^{\circ} \mathrm{S}, 00.03^{\circ} \mathrm{W}$ & 100 & $16 / 03 / 2008$ & $16: 00$ \\
\hline
\end{tabular}

preconcentration onto 8-HQ resin and chemiluminescence detection (Obata et al., 1993; modified by Sarthou et al., 2003). The comprehensive data set is published elsewhere (Chever et al., 2010). $\mathrm{H}_{2} \mathrm{O}_{2}$ samples were analyzed on board within $3 \mathrm{~h}$ of collection using a flow injection method with chemiluminescent detection (Yuan and Shiller, 1999). A comprehensive data set will be available elsewhere (Bucciarelli et al., 2011). The other ancillary parameters were measured from the closest $(15-50 \mathrm{~min})$ CTD cast. in situ $T$ and $S$ were acquired from a CTD SEABIRD SBE $911+$ mounted in a Niskin-rosette. Oxygen $\left(\mathrm{O}_{2}\right)$ concentrations were measured on board by Winkler titration. The $\mathrm{pH}$ was measured in total scale at a constant $T$ of $25^{\circ} \mathrm{C}$ $\left(\mathrm{pH}_{T, 25}\right)$ using an automated spectrophotometric technique with m-cresol purple as indicator (González-Dávila et al., 2003). A VINDTA 3C system (Mintrop et al., 2000), with coulometer determination was used for the titration of the total dissolved inorganic carbon $\left(\mathrm{C}_{\mathrm{T}}\right)$ after phosphoric acid addition. Carbonate concentration were estimated from $\mathrm{pH}_{T, 25}$, total alkalinity (potentiometrically titrated, Mintrop et al., 2000) and $\mathrm{C}_{\mathrm{T}}$, and computed by using CO2sys.xls v12 (Lewis and Wallace, 1998).

\section{Results}

\subsection{Hydrography}

The hydrography of the area is detailed in Chever et al. (2010), based on Gladyshev et al. (2008) and using the $S$ and $T$ data measured during the BGH cruise (Fig. 2). The subtropical domain (STZ) extended southward to the S-STF (about $42^{\circ} \mathrm{S}$, between station L2 and S2). Although station S2 is located south of the S-STF, its surface waters exhibit $S$ and $T$ signatures of subtropical waters. This station will be considered in the following as a Sub-Tropical station. Further south, the domain of the ACC extended to the Southern Boundary (SBdy) $\left(\sim 42^{\circ} \mathrm{S}\right.$ to $\sim 55^{\circ} \mathrm{S}$, stations $\mathrm{S} 2$ to L7). The $\mathrm{SAF}, \mathrm{PF}$ and SACCF were found at $\sim 44^{\circ} \mathrm{S}, 50^{\circ} \mathrm{S}$, and $51^{\circ} \mathrm{S}$, respectively. South of the Sbdy (station S5), waters were entrained in the large scale cyclonic flow of the Weddell gyre.

Along the transect, several major water masses were sampled. They are described elsewhere (Arhan et al., 2011; Speich et al., 2011) and briefly summarized here and on Fig. 2. In the subtropical domain, the central water layer was mostly occupied by waters of Indian Ocean origin (Boebel et al., 2003). Below, the Antarctic Intermediate Water (AAIW), the Upper Circumpolar Deep Water (UCDW), the diluted North Atlantic Deep Water (NADW), and finally the Antarctic Bottom Water (AABW) were observed. In the ACC, between the SAF and PF, below the surface mixed layer (SML) were located the AAIW, the Winter Waters (AAWW, marked by a $T$ minimum), the UCDW, and the Lower Circumpolar Deep 
Table 2. Labile Fe(II) concentrations and percentage of labile Fe(II) over dissolved Fe (DFe, Chever et al., 2010). Uncertainties on the concentrations correspond to standard deviation of a same sample measured 3 times. EWSG = eastern part of the Weddell Sea Gyre. nd= not determined, when no DFe data were available.

\begin{tabular}{|c|c|c|c|c|c|c|c|c|}
\hline Domain & Station & Position & $\begin{array}{l}\text { Bottom } \\
\text { depth (m) }\end{array}$ & $\begin{array}{r}\text { Depth } \\
(\mathrm{m})\end{array}$ & $\begin{array}{r}\mathrm{Fe}(\mathrm{II}) \\
(\mathrm{nM})\end{array}$ & $\begin{array}{l}\text { STD } \\
(\mathrm{nM})\end{array}$ & $\begin{array}{r}\mathrm{Fe}(\mathrm{II}) / \mathrm{DFe} \\
(\%)\end{array}$ & $\begin{array}{r}\text { STD } \\
(\%)\end{array}$ \\
\hline \multirow[t]{37}{*}{ Subtropical } & \multirow[t]{10}{*}{$\mathrm{L} 1$} & \multirow[t]{10}{*}{$34.43^{\circ} \mathrm{S}, 14.40^{\circ} \mathrm{E}$} & \multirow[t]{10}{*}{4505} & 20 & 0.017 & 0.001 & 7.2 & 0.6 \\
\hline & & & & 40 & 0.016 & 0.001 & 3.2 & 0.2 \\
\hline & & & & 60 & 0.025 & 0.001 & nd & \\
\hline & & & & 80 & 0.063 & 0.003 & 30.1 & 1.8 \\
\hline & & & & 200 & 0.076 & 0.004 & 10.2 & 0.5 \\
\hline & & & & 700 & 0.033 & 0.002 & 2.8 & 0.2 \\
\hline & & & & 800 & 0.049 & 0.002 & 7.7 & 0.5 \\
\hline & & & & 1000 & 0.035 & 0.002 & 5.4 & 0.3 \\
\hline & & & & 1200 & 0.017 & 0.001 & 2.7 & 0.2 \\
\hline & & & & 2100 & 0.014 & 0.001 & 2.1 & 0.1 \\
\hline & \multirow[t]{17}{*}{$\mathrm{S} 1$} & \multirow[t]{17}{*}{$36.50^{\circ} \mathrm{S} 13.10^{\circ} \mathrm{E}$} & \multirow[t]{17}{*}{4915} & 20 & 0.038 & 0.002 & 5.5 & 0.3 \\
\hline & & & & 30 & 0.039 & 0.002 & 5.5 & 0.4 \\
\hline & & & & 40 & 0.099 & 0.005 & nd & \\
\hline & & & & 70 & 0.107 & 0.005 & nd & \\
\hline & & & & 300 & 0.112 & 0.006 & nd & \\
\hline & & & & 500 & 0.107 & 0.005 & nd & \\
\hline & & & & 700 & 0.091 & 0.005 & nd & \\
\hline & & & & 1000 & 0.039 & 0.002 & 3.9 & 0.3 \\
\hline & & & & 1200 & 0.029 & 0.001 & 3.1 & 0.2 \\
\hline & & & & 1400 & 0.015 & 0.001 & 2.0 & 0.1 \\
\hline & & & & 1600 & 0.009 & 0.000 & 1.3 & 0.3 \\
\hline & & & & 2000 & 0.009 & 0.000 & nd & \\
\hline & & & & 2700 & 0.009 & 0.000 & 1.4 & 0.1 \\
\hline & & & & 3050 & 0.009 & 0.000 & 1.0 & 0.0 \\
\hline & & & & 3500 & 0.009 & 0.000 & 1.6 & 0.1 \\
\hline & & & & 3800 & 0.009 & 0.000 & 0.8 & 0.0 \\
\hline & & & & 4000 & 0.010 & 0.000 & 0.6 & 0.0 \\
\hline & \multirow[t]{10}{*}{$\mathrm{L} 2$} & \multirow[t]{10}{*}{$41.18^{\circ} \mathrm{S} 09.92^{\circ} \mathrm{E}$} & \multirow[t]{10}{*}{4525} & 15 & 0.040 & 0.002 & 25.4 & 1.3 \\
\hline & & & & 35 & 0.009 & 0.000 & nd & \\
\hline & & & & 45 & 0.009 & 0.000 & 1.5 & 0.2 \\
\hline & & & & 95 & 0.094 & 0.005 & 32.3 & 3.1 \\
\hline & & & & 300 & 0.102 & 0.005 & nd & \\
\hline & & & & 600 & 0.047 & 0.002 & 6.4 & 0.4 \\
\hline & & & & 800 & 0.025 & 0.001 & 2.3 & 0.2 \\
\hline & & & & 1200 & 0.022 & 0.001 & 2.7 & 0.2 \\
\hline & & & & 1400 & 0.015 & 0.001 & 2.0 & 0.2 \\
\hline & & & & 2100 & 0.009 & 0.000 & 1.0 & 0.1 \\
\hline
\end{tabular}

Water (LCDW) with, north of the PF, an addition of diluted South West NADW (SW-NADW, Whitworth III and Nowlin, 1987). Deeper, the AABW was observed against the northern flank of the Mid Atlantic Ridge (MAR). Finally, south of the SBdy, the near surface waters were thought to have been in contact with the western continental margin of the Antarctic Peninsula, while the deeper waters might have had a more recent contact with the northern topographic limit of the Weddell Basin (Orsi et al., 1993; Meredith et al., 2000; Klatt et al., 2005).

\subsection{Labile $\mathrm{Fe}(\mathrm{II})$ concentrations}

Labile Fe(II) concentrations are reported in Table 2 and plotted on Fig. 3a. Within the whole data set, concentrations ranged from values below the detection limit to values as high as $0.125 \mathrm{nM}$.

In the SML, labile Fe(II) concentrations were systematically higher than the detection limit. Over the whole transect, the mean value was equal to $0.039 \pm 0.024 \mathrm{nM}(n=$ 26 , median value $=0.037$ ) and concentrations ranged from $0.012 \mathrm{nM}$ to $0.116 \mathrm{nM}$. Both the minimum and maximum 
Table 2. Continued.

\begin{tabular}{|c|c|c|c|c|c|c|c|c|}
\hline Domain & Station & Position & $\begin{array}{l}\text { Bottom } \\
\text { depth (m) }\end{array}$ & $\begin{array}{r}\text { Depth } \\
(\mathrm{m})\end{array}$ & $\begin{array}{r}\mathrm{Fe}(\mathrm{II}) \\
(\mathrm{nM})\end{array}$ & $\begin{array}{l}\text { STD } \\
(\mathrm{nM})\end{array}$ & $\begin{array}{r}\mathrm{Fe}(\mathrm{II}) / \mathrm{DFe} \\
(\%)\end{array}$ & $\begin{array}{r}\text { STD } \\
(\%)\end{array}$ \\
\hline \multirow[t]{50}{*}{$\mathrm{ACC}$} & \multirow[t]{19}{*}{$\mathrm{S} 2$} & \multirow[t]{19}{*}{$42.47^{\circ} \mathrm{S} 08.93^{\circ} \mathrm{E}$} & \multirow[t]{19}{*}{4070} & 15 & 0.024 & 0.001 & 13.3 & 1.6 \\
\hline & & & & 30 & 0.019 & 0.001 & 14.6 & 2.1 \\
\hline & & & & 35 & 0.021 & 0.001 & 21.5 & 2.8 \\
\hline & & & & 45 & 0.116 & 0.006 & nd & \\
\hline & & & & 196 & 0.125 & 0.007 & 70.4 & 5.8 \\
\hline & & & & 314 & 0.105 & 0.006 & 62.3 & 4.9 \\
\hline & & & & 461 & 0.102 & 0.006 & nd & \\
\hline & & & & 598 & 0.093 & 0.005 & nd & \\
\hline & & & & 809 & 0.088 & 0.005 & 20.2 & 1.3 \\
\hline & & & & 1029 & 0.078 & 0.004 & 18.0 & 1.3 \\
\hline & & & & 1250 & 0.071 & 0.004 & 15.5 & 1.1 \\
\hline & & & & 1441 & 0.051 & 0.003 & 7.9 & 0.5 \\
\hline & & & & 1764 & 0.032 & 0.002 & 5.0 & 0.3 \\
\hline & & & & 2156 & 0.033 & 0.002 & 3.2 & 0.2 \\
\hline & & & & 2548 & 0.027 & 0.001 & 3.4 & 0.2 \\
\hline & & & & 2891 & 0.020 & 0.001 & 1.4 & 0.1 \\
\hline & & & & 3234 & 0.025 & 0.001 & 3.2 & 0.3 \\
\hline & & & & 3626 & 0.020 & 0.001 & 2.8 & 0.2 \\
\hline & & & & 3940 & 0.023 & 0.001 & 3.7 & 0.2 \\
\hline & \multirow[t]{9}{*}{ L3 } & \multirow[t]{9}{*}{$44.88^{\circ} \mathrm{S}, 06.88^{\circ} \mathrm{E}$} & \multirow[t]{9}{*}{4315} & 30 & 0.043 & 0.003 & nd & \\
\hline & & & & 100 & 0.019 & 0.002 & 9.3 & 1.7 \\
\hline & & & & 150 & 0.017 & 0.002 & 14.4 & 2.7 \\
\hline & & & & 270 & 0.023 & 0.002 & 11.6 & 1.4 \\
\hline & & & & 400 & 0.016 & 0.002 & 4.7 & 0.7 \\
\hline & & & & 600 & 0.013 & 0.001 & 3.1 & 0.4 \\
\hline & & & & 1200 & 0.009 & 0.001 & 0.9 & 0.1 \\
\hline & & & & 1400 & 0.009 & 0.001 & 1.1 & 0.1 \\
\hline & & & & 2100 & 0.011 & 0.001 & 1.8 & 0.2 \\
\hline & \multirow[t]{9}{*}{ L4 } & \multirow[t]{9}{*}{$46.02^{\circ} \mathrm{S} 05.87^{\circ} \mathrm{E}$} & \multirow[t]{9}{*}{4147} & 30 & 0.035 & 0.002 & 21.0 & 3.2 \\
\hline & & & & 60 & 0.030 & 0.002 & nd & \\
\hline & & & & 100 & 0.046 & 0.002 & 22.3 & 2.3 \\
\hline & & & & 150 & 0.023 & 0.001 & 10.1 & 1.1 \\
\hline & & & & 270 & 0.029 & 0.001 & 10.4 & 0.7 \\
\hline & & & & 480 & 0.024 & 0.001 & 6.3 & 0.7 \\
\hline & & & & 800 & 0.018 & 0.001 & 5.3 & 0.3 \\
\hline & & & & 1600 & 0.018 & 0.001 & 2.5 & 0.2 \\
\hline & & & & 2050 & 0.016 & 0.001 & 2.1 & 0.2 \\
\hline & \multirow[t]{13}{*}{$\mathrm{S} 3$} & \multirow[t]{13}{*}{$47.55^{\circ} \mathrm{S} 04.37^{\circ} \mathrm{E}$} & \multirow[t]{13}{*}{4480} & 20 & 0.065 & 0.003 & 40.2 & 7.0 \\
\hline & & & & 30 & 0.066 & 0.003 & 38.7 & 2.8 \\
\hline & & & & 40 & 0.032 & 0.002 & nd & \\
\hline & & & & 70 & 0.021 & 0.001 & 11.5 & 1.4 \\
\hline & & & & 100 & 0.018 & 0.001 & 9.6 & 1.6 \\
\hline & & & & 200 & 0.048 & 0.002 & 33.8 & 3.9 \\
\hline & & & & 300 & 0.063 & 0.003 & 22.6 & 1.4 \\
\hline & & & & 450 & 0.055 & 0.003 & 19.1 & 1.0 \\
\hline & & & & 600 & 0.050 & 0.002 & 12.2 & 0.9 \\
\hline & & & & 800 & 0.041 & 0.002 & 7.3 & 0.5 \\
\hline & & & & 1070 & 0.037 & 0.002 & 5.6 & 0.4 \\
\hline & & & & 1500 & 0.028 & 0.001 & 4.6 & 0.3 \\
\hline & & & & 2020 & 0.018 & 0.001 & 1.6 & 0.1 \\
\hline
\end{tabular}


Table 2. Continued.

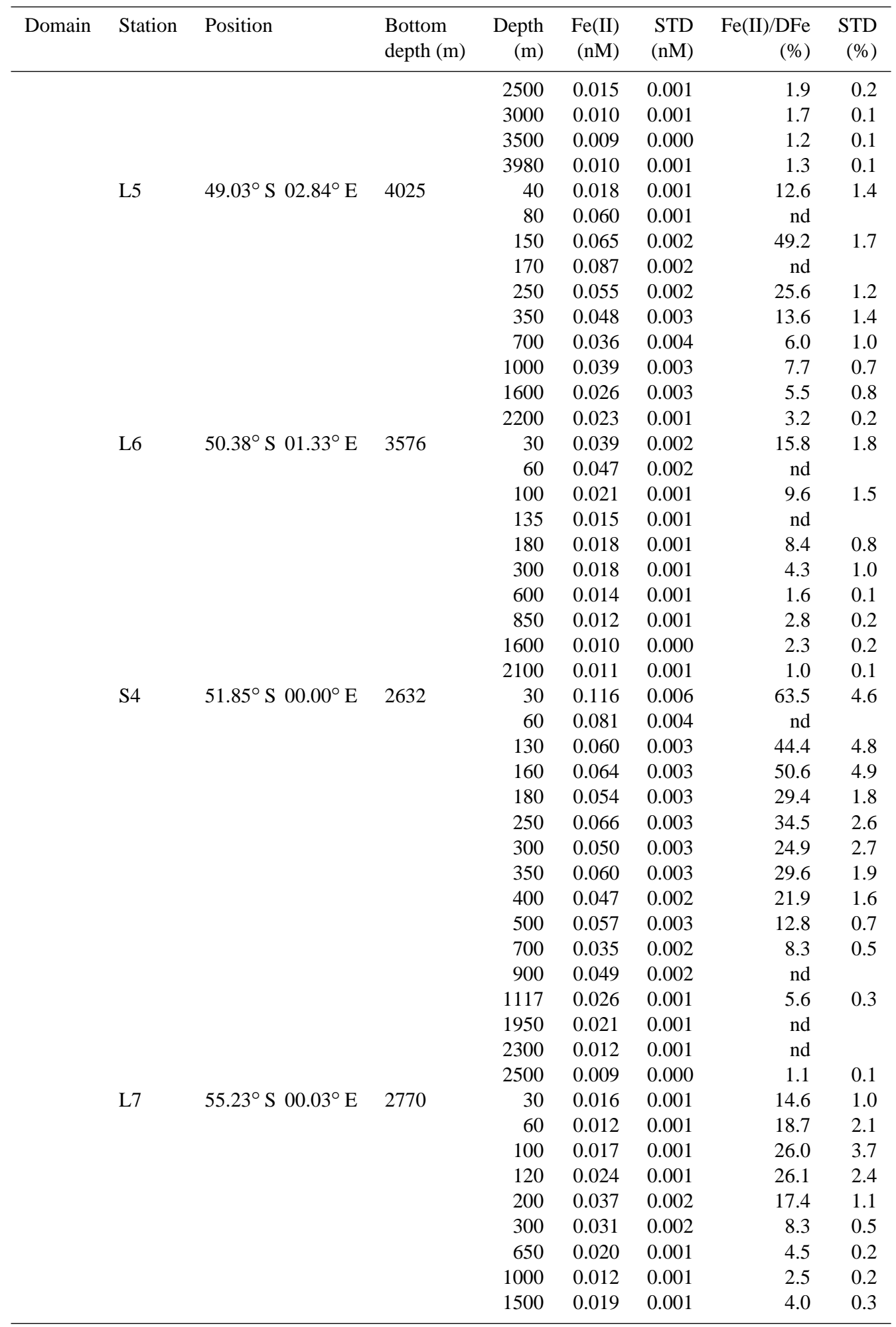


Table 2. Continued.

\begin{tabular}{|c|c|c|c|c|c|c|c|c|}
\hline Domain & Station & Position & $\begin{array}{l}\text { Bottom } \\
\text { depth }(\mathrm{m})\end{array}$ & $\begin{array}{r}\text { Depth } \\
(\mathrm{m})\end{array}$ & $\begin{array}{r}\mathrm{Fe}(\mathrm{II}) \\
(\mathrm{nM})\end{array}$ & $\begin{array}{l}\text { STD } \\
(\mathrm{nM})\end{array}$ & $\begin{array}{r}\mathrm{Fe}(\mathrm{II}) / \mathrm{DFe} \\
(\%)\end{array}$ & $\begin{array}{r}\text { STD } \\
(\%)\end{array}$ \\
\hline \multirow[t]{17}{*}{ EWSG } & S5 & $57.55^{\circ} \mathrm{S} 00.03^{\circ} \mathrm{W}$ & 3932 & 30 & 0.063 & 0.003 & 43.5 & 8.4 \\
\hline & & & & 60 & 0.042 & 0.002 & 29.2 & 2.5 \\
\hline & & & & 120 & 0.017 & 0.001 & 5.6 & 0.6 \\
\hline & & & & 140 & 0.018 & 0.001 & 16.3 & 3.4 \\
\hline & & & & 190 & 0.014 & 0.001 & 10.7 & 1.0 \\
\hline & & & & 250 & 0.025 & 0.001 & 15.0 & 1.8 \\
\hline & & & & 350 & 0.011 & 0.001 & 7.9 & 0.7 \\
\hline & & & & 550 & 0.014 & 0.001 & 8.6 & 1.0 \\
\hline & & & & 750 & 0.021 & 0.001 & 2.9 & 0.5 \\
\hline & & & & 800 & 0.024 & 0.001 & 7.1 & 0.5 \\
\hline & & & & 1250 & 0.009 & 0.000 & 2.2 & 0.1 \\
\hline & & & & 1700 & 0.009 & 0.000 & 3.5 & 0.2 \\
\hline & & & & 2150 & 0.035 & 0.002 & 12.2 & 0.7 \\
\hline & & & & 2600 & 0.036 & 0.002 & 10.0 & 0.9 \\
\hline & & & & 3050 & 0.047 & 0.002 & 11.2 & 0.6 \\
\hline & & & & 3500 & 0.050 & 0.003 & 13.1 & 0.8 \\
\hline & & & & 3840 & 0.044 & 0.002 & 8.5 & 0.8 \\
\hline
\end{tabular}

values were observed in the ACC (Station L7, 60 m, and station $\mathrm{S} 4,30 \mathrm{~m}$, respectively). The highest percentages of $\mathrm{Fe}$ (II) relative to DFe (40-64\%, Fig. 3b) were found at three stations south of $47^{\circ} \mathrm{S}(\mathrm{S} 3, \mathrm{~S} 4$, and S5) and were associated with values of $\mathrm{Fe}(\mathrm{II})$ higher than $0.060 \mathrm{nM}$. At the other stations, percentages were lower, ranging from $3 \%$ to $25 \%$.

At intermediate depth (between the SML and $1500 \mathrm{~m}$ ), values ranged from below the detection limit to $0.125 \mathrm{nM}$ (Station S2, $196 \mathrm{~m}$ ). The maxima observed around 200$300 \mathrm{~m}$, more pronounced in the sub-tropical zone, corresponded to percentages of labile $\mathrm{Fe}(\mathrm{II})$ relative to $\mathrm{DFe}$ of $30 \%$ to $70 \%$. Elsewhere, percentages varied between less than $1 \%$ and $26 \%$.

Below $1500 \mathrm{~m}$, labile Fe(II) concentrations were generally close to or below the detection limit (mean value $0.010 \pm 0.002 \mathrm{nM}, n=11$ ), representing less than $4 \%$ of DFe. Exceptions were noted at station S2, where values were around $0.030 \mathrm{nM}$ at $\sim 2000 \mathrm{~m}$, and at station $\mathrm{S} 5$ where values ranged from 0.035 to $0.050 \mathrm{nM}$ below $2100 \mathrm{~m}$,

\section{3 $\mathrm{Fe}(\mathrm{II})$ oxidation rates}

The natural logarithm transformation of Fe(II) chemiluminescence over time showed linear decreases in signal for all surface and deep samples and spike additions, indicating a pseudo first-order kinetics for Fe(II) oxidation during the timescale monitored (Fig. 4). The pseudo-first order rate constants $k_{\text {ox }}$ at $4{ }^{\circ} \mathrm{C}$ were experimentally determined as the slope of the ln-transformed chemiluminescence signal vs. time. The half-lives $\left(t_{1 / 2}\right)$ were then calculated as $t_{1 / 2}=$ $\ln (2) / k_{\text {ox }}$, for the four Fe(II) spikes (Fig. 5, Table 3). These measured half-lives of $\mathrm{Fe}(\mathrm{II})$ at (sub-)nanomolar concentra- tions will be compared to theoretical values derived from model predictions.

In the upper waters (20-300 m), values ranged from 2.9 to $11.3 \mathrm{~min}$ and increased significantly with latitude (linear regression, $r^{2}=0.65$, slope $=0.3 \mathrm{~min} /{ }^{\circ} \mathrm{S}, P<0.01, n=12$ ). The mean value of all data was equal to $6.7 \pm 2.6 \mathrm{~min}$ (median value $6.7 \mathrm{~min})$. In the deep waters $(300-2000 \mathrm{~m}), t_{1 / 2}$ varied between 10.0 and $72.3 \mathrm{~min}$, and no significant relationship was observed with latitude (linear regression, $P=$ 0.57). The mean value of all the deep-water data was equal to $37.0 \pm 19.7 \mathrm{~min}$ (median value $35.2 \mathrm{~min}$ ). On average, the measured $t_{1 / 2}$ was 6 times higher in deep waters than in the upper waters. At the four super stations where two different depths were sampled below $300 \mathrm{~m}$, values were not significantly different (paired t-test, $P=0.6, n=4$ ).

\section{Discussion}

\subsection{Comparison with previously reported $\mathrm{Fe}(\mathrm{II})$ data}

There are relatively few Fe(II) data reported in the literature (Table 4). Previous studies have been either generally geographically restricted, except the one carried out by Hansard et al. (2009), or focused on particular areas, such as the suboxic zones, or performed during artificial $\mathrm{Fe}$ experiments in the Southern Ocean or the Subarctic Pacific.

For the open ocean, measurements were done in the Pacific Ocean (Hansard et al., 2009; O'Sullivan et al., 1991), the Atlantic Ocean (Bowie et al., 2002; Boye et al., 2003, 2006), and the Southern Ocean (Croot et al., 2007). These studies typically found $\mathrm{Fe}$ (II) concentrations ranging from 


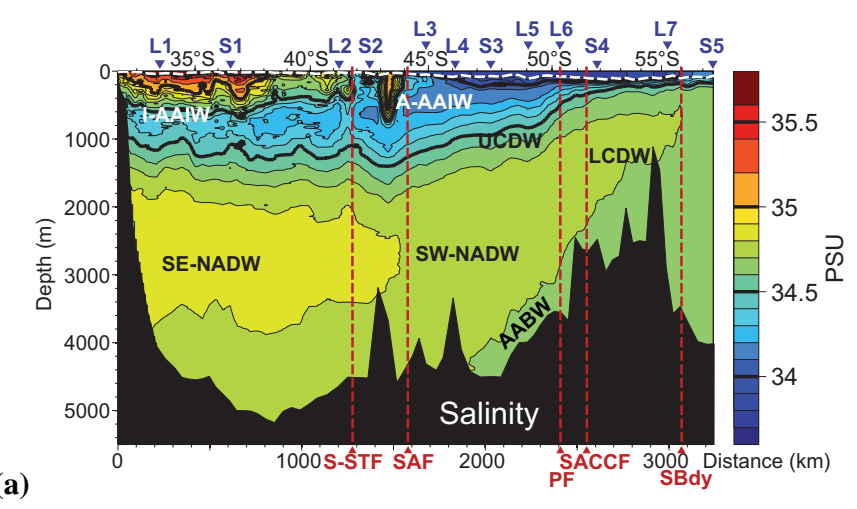

(a)

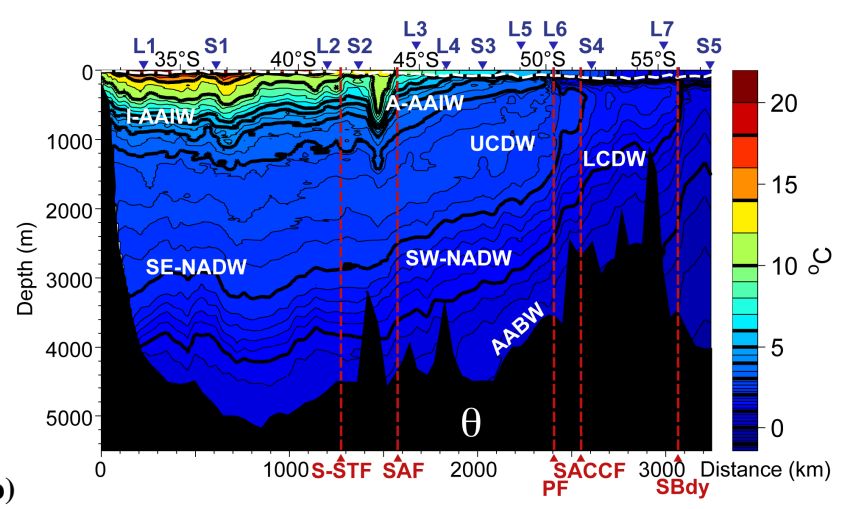

(b)

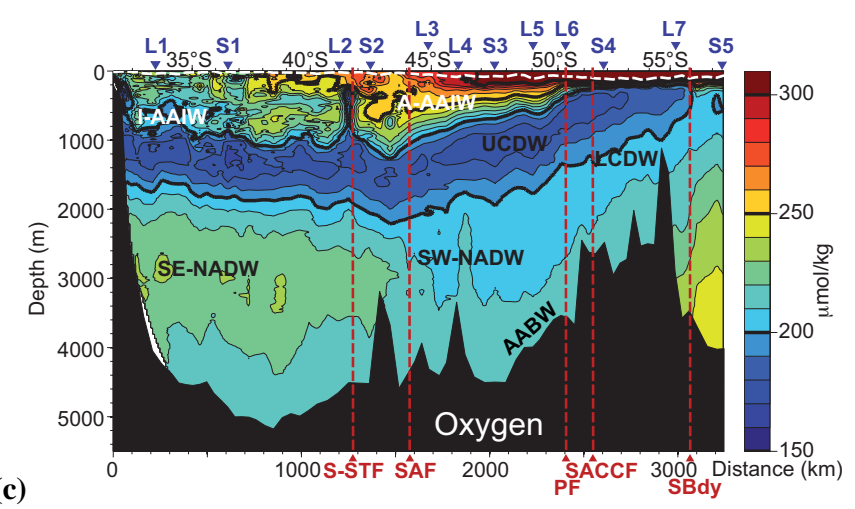

Fig. 2. Vertical distribution of salinity (a), theta (b), and oxygen (c) measured along the transect from the north (left) to the south (right) of the section. Water masses are indicated: AAIW: Antarctic Intermediate Water. This water mass is coming from the Indian Ocean through the Agulhas Current (I-AAIW) north of $\sim 37^{\circ} \mathrm{S}$ and from the Atlantic sector (A-AAIW) south of $37^{\circ} \mathrm{S}$ (Gordon et al., 1992). NADW: North Atlantic Deep Water. The highest salinity values close to the African continental slope reflect advection by a southeastward deep boundary current (SE-NADW, Arhan et al., 2003). LCDW: Lower Circumpolar Deep Water and AABW: Antarctic Bottom Water.

the detection limit to $\sim 0.050-0.080 \mathrm{nM}$, with higher concentrations in the surface waters, due to photoproduction processes, or in water masses influenced by continental mar-

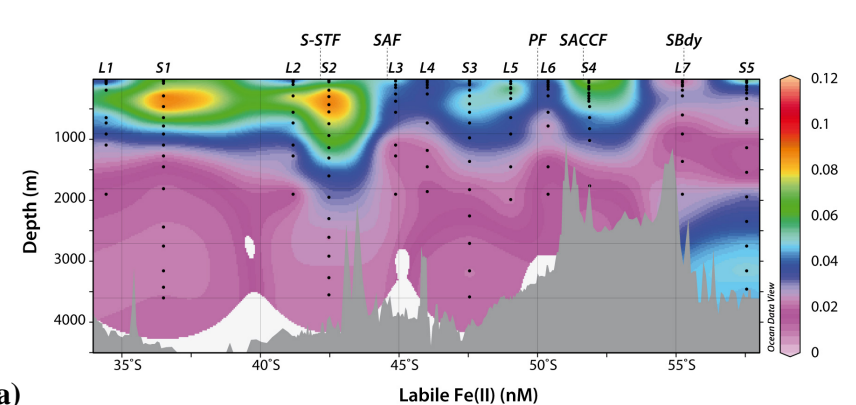

(a)

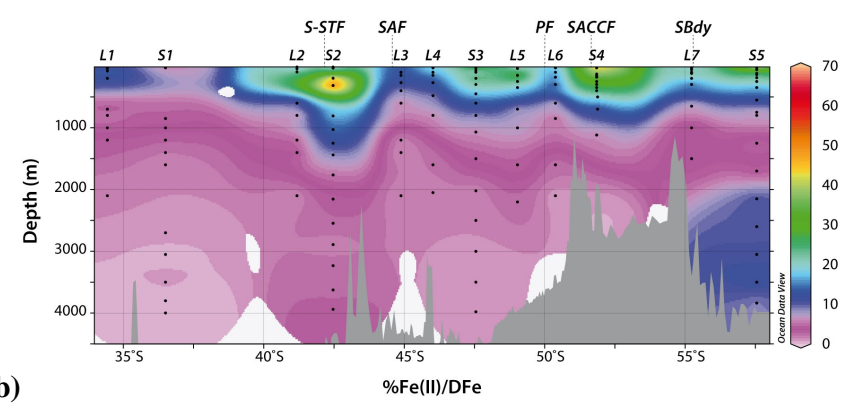

Fig. 3. Vertical section of (a) labile $\mathrm{Fe}$ (II) in $\mathrm{nM}$ and (b) $\% \mathrm{Fe}(\mathrm{II}) / \mathrm{DFe}$ from the north (left) to the south (right) of the section. DFe data are from Chever et al. (2010).

gins. Indeed, studies carried out in continental or shelf waters showed concentrations up to $0.3-0.5 \mathrm{nM}$ (Boye et al., 2006; Hansard et al., 2009), and even $3 \mathrm{nM}$ (Waite et al., 1995). These high concentrations were likely due to transport of sediment-derived Fe and/or diffusion of $\mathrm{Fe}(\mathrm{II}) \mathrm{di}$ rectly from pore waters. These processes were even more pronounced in Fe-rich coastal environments, where values of $\mathrm{Fe}(\mathrm{II})$ were found to reach $40 \mathrm{nM}$ (Hong and Kester, 1986). In suboxic zones, low oxygen concentrations slow the oxidation of $\mathrm{Fe}(\mathrm{II})$ and maxima of $\mathrm{Fe}(\mathrm{II})(0.2-0.6 \mathrm{nM})$ were associated with the oxygen minima and/or nitrite maxima (Hopkison and Barbeau, 2007; Moffett et al., 2007). During the artificial Fe fertilization experiments, concentrations of $\mathrm{Fe}$ (II) were shown to remain elevated ( $>0.2 \mathrm{nM}$ and up to $1 \mathrm{nM}$ ) for several days after enrichment (Croot et al., 2001, 2005, 2008; Croot and Laan, 2002), due to a potential combination of slow oxidation rate or possibly due to organic complexation of Fe(II) (Roy et al., 2008).

Our values are within these reported ranges, although most of the previous studies measured $\mathrm{Fe}(\mathrm{II})$ in the dissolved phase. As already mentioned in Sect 2.2, omitting the filtration may underestimate or overestimate the $\mathrm{Fe}(\mathrm{II})$ signal, but the good consistency between our data set and previous ones suggests that any bias is minimal. Our range of concentrations was also reasonably consistent with that of Hansard et al. (2009). In that study, samples were acidified to $\mathrm{pH}$ 6 to minimize $\mathrm{Fe}(\mathrm{II})$ oxidation prior to analysis. A concern was that the acidification step may result in a measurement of "readily reducible Fe(III)" rather than actual Fe(II); however, 

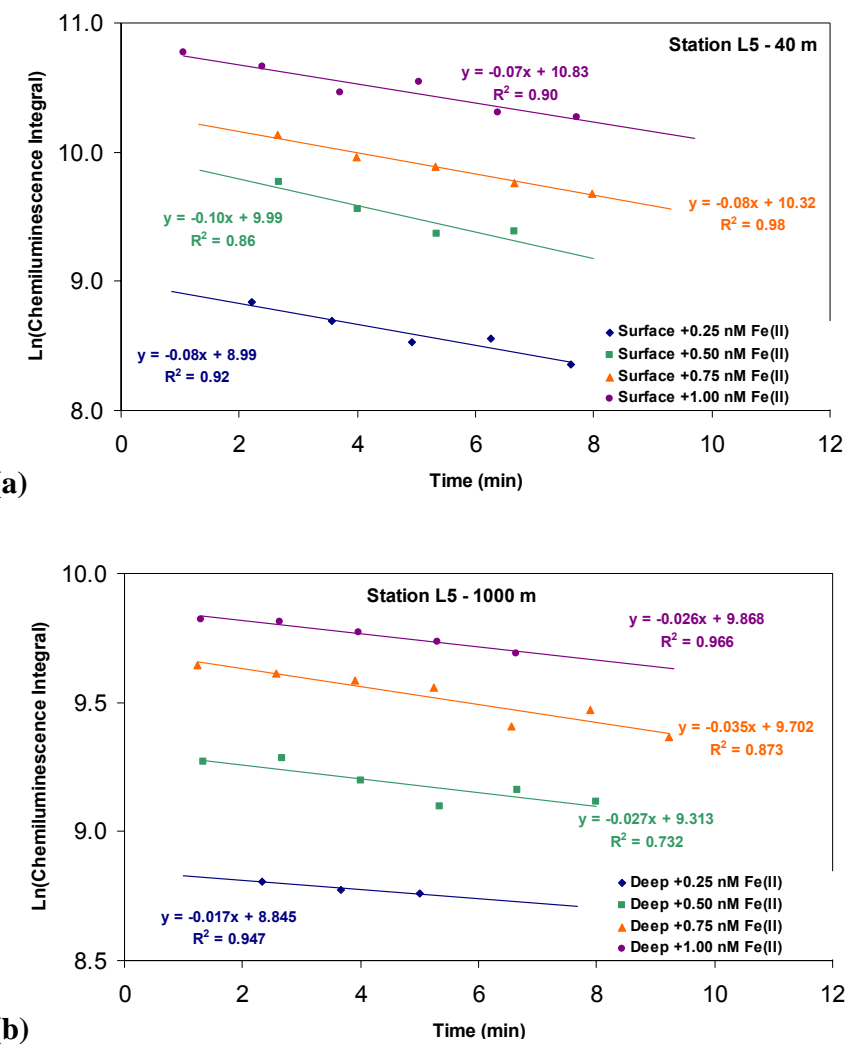

Fig. 4. Natural logarithm transformation of the chemiluminescent integral vs. time for $\mathrm{Fe}(\mathrm{II})$ spikes $(0.25-1 \mathrm{nM})$ in a surface sample (a) and a deep one (b). See text for more details.

the similarity between the two data sets suggests that the method of Hansard et al. (2009) adequately corrected for any $\mathrm{Fe}$ (III) reduction that may have been caused by $\mathrm{pH}$ adjustment.

\subsection{Spatial and vertical distribution of labile $\mathrm{Fe}(\mathrm{II})$ during the BGH cruise}

In contrast to DFe concentrations (Chever et al., 2010), no systematic decrease in labile $\mathrm{Fe}(\mathrm{II})$ concentrations was observed from the north to the south of the section. The high values of DFe in the STZ were suggested to be due to direct dust deposition coming from Patagonia and/or to lateral advection of Indian Ocean water masses enriched by dust inputs. Another potential source of DFe was the African continental margin both in the SML and deeper waters (Chever et al., 2010). The mean advective time of these waters, estimated from the AVISO Mean Absolute Dynamic Topography (Ducet et al., 2000) for both the specific cruise period (2007-2008) and for the entire satellite time series (i.e., from 1992 to 2008), was equal to $1-3$ months. Given the very short half-life time of Fe(II) in surface and deep waters (3$72 \mathrm{~min}$ ), this delay is likely to be too long to preserve the signal of a potential enrichment of water masses by the African

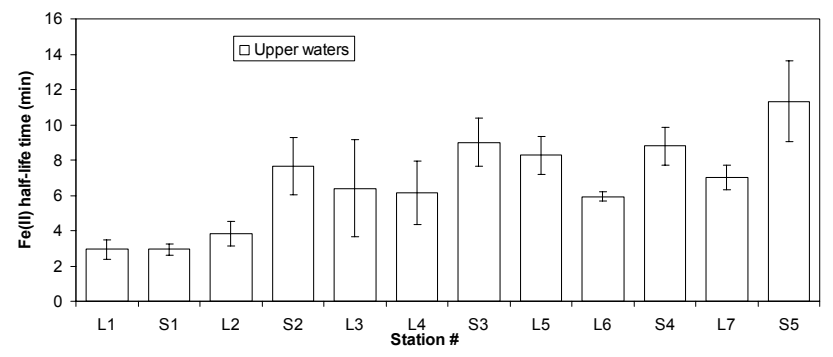

(a)

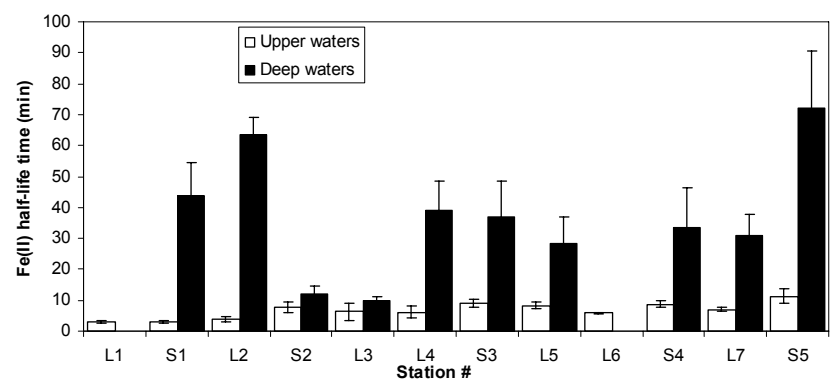

(b)

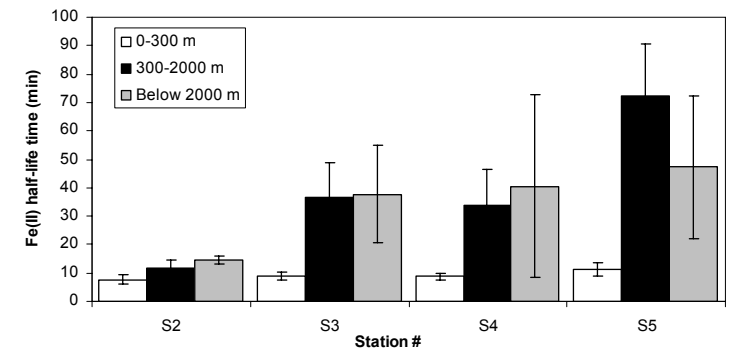

(c)

Fig. 5. Measured $\mathrm{Fe}(\mathrm{II})$ half-lifes at $4^{\circ} \mathrm{C}$ in minutes for (a) surface waters $(20-300 \mathrm{~m})$, (b) both surface and deep waters (300$2000 \mathrm{~m}$ ), and (c) surface, 300-2000 m deep and 2300-3600 m deep waters. The bars represent the mean value calculated from the four Fe spikes and the error bars the standard deviation.

continental margin, unless stabilization of $\mathrm{Fe}(\mathrm{II})$ by organic complexation occurs (Roy et al., 2008). In the following, we will examine in more detail the depth profiles of labile Fe(II) and discuss the potential sources of $\mathrm{Fe}$ (II) in our studied area.

\subsubsection{Surface mixed layer (SML)}

Diurnal variation in Fe redox speciation in the SML has been observed in numerous studies (e.g. Hong and Kester, 1986; Johnson et al., 1994; O'Sullivan et al., 1991; Waite et al., 1995; Bowie et al., 2002; Roy et al., 2008). In our study, 5 stations were sampled at night (S1, L2, L4, L6 and L7) and 7 stations were sampled during the day (L1, S2, L3, S3, L5, S4 and S5). The daytime and nighttime mean values were not significantly different $(0.044 \pm 0.029 \mathrm{nM}$ and $0.033 \pm 0.012 \mathrm{nM}$, respectively, student's t-test, $P=0.39$ ). Unexpectedly, daytime values were negatively correlated to 
Table 3. Theoretical values of Fe(II) half lifes (in min) for surface and deep water samples at $4{ }^{\circ} \mathrm{C}$ using models of Fe(II) oxidation kinetics (Santana-Casiano et al., 2005: Model I; Trapp and Millero, 2007: Model II; see Supplement). The ionic strength has been calculated from salinity using the equation $I=(19.9201 * \mathrm{~S}) /(1000-1.00488 * \mathrm{~S})$ (Millero, 1995).

\begin{tabular}{|c|c|c|c|c|c|c|c|c|c|}
\hline \multirow[b]{2}{*}{ Stations } & \multirow[b]{2}{*}{ Latitude $\left({ }^{\circ} \mathrm{S}\right)$} & \multirow[b]{2}{*}{$I(M)$} & \multirow[b]{2}{*}{$\begin{array}{l}{\left[\mathrm{O}_{2}\right]} \\
(\mu \mathrm{M})\end{array}$} & \multirow[b]{2}{*}{$\begin{array}{r}{\left[\mathrm{H}_{2} \mathrm{O}_{2}\right]} \\
(\mathrm{nM})\end{array}$} & \multirow[b]{2}{*}{$\mathrm{pH}$} & \multirow[b]{2}{*}{$\begin{array}{r}{\left[\mathrm{CO}_{3}^{2-}\right]} \\
(\mu \mathrm{M})\end{array}$} & \multicolumn{2}{|c|}{ Theoretical values } & \multirow{2}{*}{$\begin{array}{r}\text { Measured } \\
\text { values } \\
t 1 / 2 \text { (min) }\end{array}$} \\
\hline & & & & & & & $\begin{array}{c}\text { Model I } \\
t 1 / 2(\min )\end{array}$ & $\begin{array}{c}\text { Model II } \\
t 1 / 2(\min )\end{array}$ & \\
\hline \multicolumn{10}{|l|}{ Upper waters } \\
\hline L1 & 34.43 & 0.74 & 233.7 & 27.0 & 8.09 & 216.1 & 7.5 & 5.5 & 2.9 \\
\hline $\mathrm{S} 1$ & 36.50 & 0.73 & 245.4 & 19.6 & 8.12 & 209.1 & 7.7 & 5.6 & 2.9 \\
\hline L2 & 41.18 & 0.71 & 251.3 & 2.4 & 7.99 & 110.3 & 18.4 & 13.6 & 3.8 \\
\hline $\mathrm{S} 2$ & 42.47 & 0.71 & 273.5 & 2.1 & 8.04 & 117.9 & 15.4 & 11.4 & 7.6 \\
\hline L3 & 44.88 & 0.70 & 293.2 & & 8.07 & 128.0 & 12.6 & 9.7 & 6.4 \\
\hline L4 & 46.02 & 0.70 & 300.9 & 21.5 & 8.07 & 125.0 & 11.3 & 9.0 & 6.2 \\
\hline S3 & 47.55 & 0.70 & 311.3 & 15.1 & 8.08 & 119.8 & 12.0 & 9.4 & 9.0 \\
\hline L5 & 49.03 & 0.70 & 313.5 & 19.8 & 8.07 & 120.0 & 11.6 & 9.2 & 8.3 \\
\hline L6 & 50.38 & 0.70 & 326.2 & 22.6 & 8.08 & 112.1 & 12.2 & 9.6 & 5.9 \\
\hline $\mathrm{S} 4$ & 51.85 & 0.69 & 340.7 & 9.0 & 8.05 & 106.1 & 13.4 & 10.4 & 8.8 \\
\hline L7 & 55.23 & 0.70 & 349.2 & 31.1 & 8.06 & 98.8 & 13.1 & 10.3 & 7.0 \\
\hline S5 & 57.55 & 0.70 & 353.3 & 31.5 & 8.06 & 93.9 & 14.1 & 10.9 & 11.3 \\
\hline \multicolumn{10}{|l|}{ Deep waters } \\
\hline $\mathrm{S} 1$ & 36.50 & 0.72 & 218.0 & & 7.93 & 90.5 & 91.1 & 20.4 & 43.8 \\
\hline L2 & 41.18 & 0.71 & 187.7 & 1.1 & 7.85 & 74.6 & 127.0 & 30.8 & 63.4 \\
\hline $\mathrm{S} 2$ & 42.47 & 0.71 & 185.4 & & 7.86 & 75.3 & 132.6 & 31.0 & 11.8 \\
\hline $\mathrm{S} 2$ & 42.47 & 0.72 & 227.8 & & 7.88 & 91.3 & 85.6 & 19.2 & 14.6 \\
\hline L3 & 44.88 & 0.71 & 185.5 & & 7.85 & 76.2 & 130.5 & 30.5 & 10.0 \\
\hline $\mathrm{L} 4$ & 46.02 & 0.72 & 187.0 & & 7.87 & 85.5 & 114.8 & 26.1 & 39.2 \\
\hline S3 & 47.55 & 0.71 & 181.2 & & 7.86 & 74.5 & 137.6 & 32.3 & 36.7 \\
\hline $\mathrm{S} 3$ & 47.55 & 0.72 & 218.7 & & 7.84 & 81.7 & 101.3 & 23.3 & 37.6 \\
\hline L5 & 49.03 & 0.71 & 180.5 & 1.4 & 7.85 & 77.6 & 125.5 & 30.3 & 28.2 \\
\hline $\mathrm{S} 4$ & 51.85 & 0.71 & 183.9 & & 7.88 & 79.5 & 126.7 & 29.2 & 33.6 \\
\hline $\mathrm{S} 4$ & 51.85 & 0.72 & 218.5 & & 7.87 & 84.0 & 98.8 & 22.6 & 40.5 \\
\hline L7 & 55.23 & 0.72 & 201.9 & 6.3 & 7.92 & 84.4 & 89.9 & 23.4 & 30.9 \\
\hline S5 & 57.55 & 0.72 & 209.1 & & 7.91 & 76.8 & 115.8 & 26.8 & 72.3 \\
\hline S5 & 57.55 & 0.72 & 252.4 & & 7.85 & 79.7 & 89.8 & 20.8 & 47.2 \\
\hline
\end{tabular}

the SML-integrated solar radiation (ANOVA, $F=9.12, P<$ 0.01, E. Key, personal communication, 2011). A parameter that appeared to control the labile Fe(II) values in our data set was the time at which samples were taken. Indeed, maximum values of labile $\mathrm{Fe}$ (II) as well as $\% \mathrm{Fe}$ (II)/DFe were observed for the three stations (S3, S4 and S5) sampled between 12:00 and 16:00 (Universal Time, Fig. 6). This is consistent with photochemical reactions producing Fe(II) in the SML (Rich and Morel, 1990; Wells et al., 1991; Kuma et al., 1992a, b; King et al., 1993; Barbeau et al., 2001; Rijkenberg et al., 2006; Voelker and Sedlak, 1995; Rose and Waite, 2002, 2003; Kustka et al., 2005; Rose et al., 2005; Roy et al., 2008). However, at these stations, the time between the tripping of the Go-Flo bottles (removing the sample from the influence of light) and analysis (30-40 min) was greater than the measured half-life times of $\mathrm{Fe}$ (II) (9-11 min). Under these circumstances, unrealistically high intial $\mathrm{Fe}$ (II) concentrations would be predicted (3-4 times DFe), suggesting that other source mechanisms (e.g. biological production) may be operating. Daily biological Fe(II) production cycles might overlap with photochemical ones, since higher photosynthetic efficiencies have been observed to occur around noon (Legendre et al., 1988). Moreover, one metabolic pathway for biological production of superoxide, an active oxygen redox intermediate capable of reducing Fe(III), appears to be associated with increased irradiance (Marshall et al., 2001).

Biological superoxide production rates were recently measured in oceanic and coastal waters of the Gulf of Alaska, with values as high as $0.3 \mathrm{nM} \mathrm{min}^{-1}$ (Hansard et al., 2010). Considering our labile Fe(II) data and measured $t_{1 / 2}$, and assuming steady-state, the calculated $\mathrm{Fe}$ (II) production rate was about $0.002-0.013 \mathrm{nM} \mathrm{min}^{-1}$. Although inducing a potential overestimation of the labile $\mathrm{Fe}(\mathrm{II})$ measurement, the production rates of superoxide were thus likely sufficient to 
Table 4. Fe(II) concentration ranges in previous published studies.

\begin{tabular}{|c|c|c|c|c|}
\hline $\begin{array}{l}\text { Latitude/ } \\
\text { Longitude }\end{array}$ & $\begin{array}{l}\text { Environments/ } \\
\text { Experiments }\end{array}$ & $\begin{array}{l}\text { Depth } \\
\text { range }(\mathrm{m})\end{array}$ & $\begin{array}{l}{[\mathrm{Fe}(\mathrm{II})]} \\
\text { range }\end{array}$ & Reference \\
\hline $\begin{array}{l}33.43^{\circ} \mathrm{S}-57.55^{\circ} \mathrm{S} / \\
14.40^{\circ} \mathrm{E}-00.03^{\circ} \mathrm{W}\end{array}$ & $\begin{array}{l}\text { Open Ocean } \\
\text { South Atlantic/Southern Ocean }\end{array}$ & $15-4000 \mathrm{~m}$ & $0.09-0.125 \mathrm{nM}$ & This study \\
\hline $\begin{array}{l}30^{\circ} \mathrm{N} / 135^{\circ} \mathrm{E}-118^{\circ} \mathrm{W} \\
14^{\circ} \mathrm{S}-56^{\circ} \mathrm{N} / 152^{\circ} \mathrm{W}\end{array}$ & $\begin{array}{l}\text { Open Ocean Pacific Ocean and } \\
\text { northern Philippine Sea }\end{array}$ & $13-1010 \mathrm{~m}$ & $\begin{array}{l}<0.012-0.28 \mathrm{nM} \\
<0.012-0.76 \mathrm{nM}\end{array}$ & Hansard et al. (2009) \\
\hline $3.0^{\circ} \mathrm{S}-9.1^{\circ} \mathrm{N} / 140^{\circ} \mathrm{W}$ & $\begin{array}{l}\text { Open Ocean } \\
\text { Equatorial Pacific }\end{array}$ & $0-100 \mathrm{~m}$ & $<0.12-0.53 \mathrm{nM}$ & O’Sullivan et al.( 1991) \\
\hline $178.72^{\circ} \mathrm{E} / 46.24^{\circ} \mathrm{S}$ & $\begin{array}{l}\text { Open Ocean, South West Pacific, } \\
\text { FeCycle experiment. }\end{array}$ & $2 \mathrm{~m}$ & $\begin{array}{l}\text { Up to } 0.046 \mathrm{nM} \\
\text { (during night-time) }\end{array}$ & Croot et al. (2007) \\
\hline $\begin{array}{l}23^{\circ} 18^{\prime} \mathrm{S}-24^{\circ} 48^{\prime} \mathrm{S} / \\
8^{\circ} 39^{\prime} \mathrm{E}-9^{\circ} 59^{\prime} \mathrm{E}\end{array}$ & Open Ocean, South Atlantic & $1-2 \mathrm{~m}$ & $<0.012-0.045 \mathrm{nM}$ & Bowie et al. (2002) \\
\hline $\begin{array}{l}50^{\circ} 92^{\prime} \mathrm{S}-51^{\circ} 25^{\prime} \mathrm{S} / \\
143^{\circ} 38^{\prime} \mathrm{E}-143^{\circ} 03^{\prime} \mathrm{E}\end{array}$ & $\begin{array}{l}\text { Open Ocean, Southern Ocean, } \\
\text { Subantarctic Front }\end{array}$ & $1-2 \mathrm{~m}$ & $<0.012-0.029 \mathrm{nM}$ & Bowie et al. (2002) \\
\hline $42-51^{\circ} \mathrm{N} / 23^{\circ} \mathrm{E}-2^{\circ} \mathrm{W}$ & $\begin{array}{l}\text { Eastern North Atlantic, } \\
\text { European continental shelf } \\
\text { and English Channel }\end{array}$ & $2 \mathrm{~m}$ & $\begin{array}{l}<0.16 \mathrm{nM} \\
\text { (oceanic waters) } \\
\text { Up to } 0.25 \mathrm{nM} \\
\text { (shelf waters) } \\
0.5-1.8 \mathrm{nM} \\
\text { (coastal waters). }\end{array}$ & Boye et al. (2003) \\
\hline $37-42^{\circ} \mathrm{N} / 23^{\circ} \mathrm{W}$ & Eastern North Atlantic & $0-2000 \mathrm{~m}$ & $<0.1-0.55 \mathrm{nM}$ & Boye et al. (2006) \\
\hline $\begin{array}{l}46^{\circ} \mathrm{N}-52.4^{\circ} \mathrm{N} / \\
8^{\circ} \mathrm{W}-4.3^{\circ} \mathrm{E}\end{array}$ & $\begin{array}{l}\text { European continental margin. } \\
\text { Open Ocean and shelf waters }\end{array}$ & $3-4000 \mathrm{~m}$ & $<0.012 \mathrm{nM}->0.2 \mathrm{nM}$ & Ussher et al. (2007) \\
\hline $\begin{array}{l}9.02^{\circ} \mathrm{S}-12.27^{\circ} \mathrm{S} / \\
127.43^{\circ} \mathrm{E}-144.19^{\circ} \mathrm{E}\end{array}$ & Northern Australian shelf waters & $2-3 \mathrm{~m}$ & Up to $3 \mathrm{nM}$ & Waite et al. (1995) \\
\hline $\begin{array}{l}31.53^{\circ} \mathrm{N}-56.50^{\circ} \mathrm{N} / \\
0.39^{\circ} \mathrm{E}-0.83^{\circ} \mathrm{E}\end{array}$ & Northern North Sea & $0-70 \mathrm{~m}$ & Up to $1.2 \mathrm{nM}$ & $\begin{array}{l}\text { Gledhill and van den } \\
\text { Berg (1995) }\end{array}$ \\
\hline $\begin{array}{l}9.5^{\circ} \mathrm{S}-10.9^{\circ} \mathrm{S} / \\
78.1^{\circ} \mathrm{W}-79.1^{\circ} \mathrm{W}\end{array}$ & $\begin{array}{l}\text { Suboxic zone, near the coast } \\
\text { of Peru }\end{array}$ & $0-2300 \mathrm{~m}$ & Up to $40 \mathrm{nM}$ & $\begin{array}{l}\text { Hong and Kester } \\
\text { (1986) }\end{array}$ \\
\hline $\begin{array}{l}17^{\circ} \mathrm{N}-23.5^{\circ} \mathrm{N} / \\
57^{\circ} \mathrm{E}-74^{\circ} \mathrm{E}\end{array}$ & Suboxic zone, Arabian Sea & $0-1000 \mathrm{~m}$ & Up to $0.6 \mathrm{nM}$ & Moffett et al. (2007) \\
\hline $\begin{array}{l}15^{\circ} \mathrm{N}-18^{\circ} \mathrm{N} / \\
105^{\circ} \mathrm{W}-115^{\circ} \mathrm{W}\end{array}$ & $\begin{array}{l}\text { Oxic-suboxic zone, Eastern } \\
\text { Tropical North Pacific }\end{array}$ & $0-300 \mathrm{~m}$ & Up to $0.15 \mathrm{nM}$ & $\begin{array}{l}\text { Hopkison and } \\
\text { Barbeau (2007) }\end{array}$ \\
\hline $61^{\circ} \mathrm{S} / 140^{\circ} \mathrm{E}$ & $\begin{array}{l}\text { Southern Ocean SOIREE } \\
\text { fertilization experiment }\end{array}$ & $2-3 \mathrm{~m}$ & Up to $1 \mathrm{nM}$ & Croot et al. (2001) \\
\hline $48^{\circ} \mathrm{S} / 21^{\circ} \mathrm{E}$ & $\begin{array}{l}\text { Southern Ocean EISENEX } \\
\text { fertilization experiment }\end{array}$ & $0-100 \mathrm{~m}$ & Up to $1 \mathrm{nM}$ & $\begin{array}{l}\text { Croot and Laan (2002); } \\
\text { Croot et al. (2005) }\end{array}$ \\
\hline $56.2^{\circ} \mathrm{S}-66^{\circ} \mathrm{S} / 172^{\circ} \mathrm{W}$ & $\begin{array}{l}\text { Southern Ocean SOFEX } \\
\text { fertilization experiment }\end{array}$ & $2-3 \mathrm{~m}$ & $\begin{array}{l}\text { Up to } 0.3 \mathrm{nM} \\
\text { in patch }\end{array}$ & Croot et al. (2008) \\
\hline $50^{\circ} \mathrm{S} / 2^{\circ} \mathrm{E}$ & $\begin{array}{l}\text { Southern Ocean EIFEX } \\
\text { fertilization experiment }\end{array}$ & $2-3 \mathrm{~m}$ & $\begin{array}{l}\text { Up to } 0.8 \mathrm{nM} \\
\text { in patch }\end{array}$ & Croot et al. (2008) \\
\hline $46.7^{\circ} \mathrm{N} / 165.8^{\circ} \mathrm{E}$ & $\begin{array}{l}\text { Sub-Arctic Pacific Ocean SEEDS } \\
\text { II fertilization experiment }\end{array}$ & $0-80 \mathrm{~m}$ & $\begin{array}{l}\mathrm{Up} \text { to }>0.2 \mathrm{nM} \\
\text { in patch }\end{array}$ & Roy et al. (2008) \\
\hline
\end{tabular}




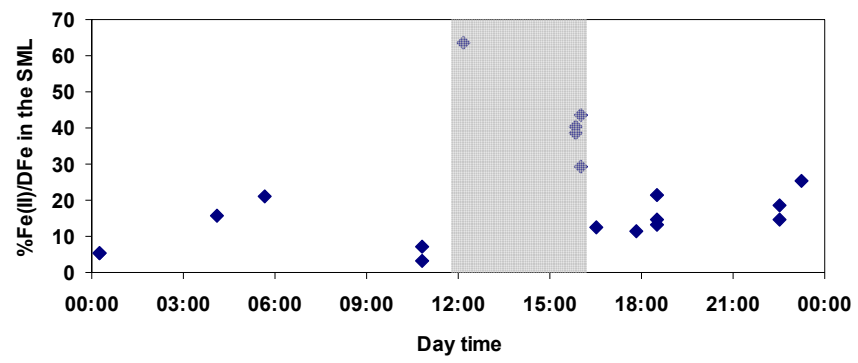

Fig. 6. Percentage of labile Fe(II) relative to dissolved Fe concentrations in the surface mixed layer for all the stations vs. the time at which sampling was done.

drive $\mathrm{Fe}(\mathrm{II})$ production. If a biological production exists in the surface waters, that would explain our values higher than the detection limit even at stations sampled at night. This night time observation of $\mathrm{Fe}(\mathrm{II})$ at $\mathrm{pM}$ levels was already done during the FeCycle experiment in the HNLC waters of the South West Pacific (Croot et al., 2007). These authors estimated that $\sim 26 \%$ of the inorganic Fe(II) biologically produced would be organically complexed and the rest would be oxidized.

During the ANT XXIV/3 cruise (10 February-14 April 2008), maxima of DFe and dissolved manganese (Mn) were observed in the surface waters in the Bouvet region at 54$55^{\circ} \mathrm{S}$ (Klunder et al., 2011; Middag et al., 2011), and were ascribed to recent deposition of aeolian dust originating from South America. At our L7 station $\left(\sim 55^{\circ} \mathrm{S}\right)$, however, no surface maximum of labile Fe(II) was observed, neither clear surface maxima of DFe in the Bouvet region (Chever et al., 2010). This may be due to the fact that our sampling was performed three weeks later than theirs and/or to our lower sampling resolution, missing some of the key features they observed in the Bouvet region. At station $\mathrm{S} 4\left(\sim 52^{\circ} \mathrm{S}\right)$, where we observed the highest value of labile Fe(II) in the SML, a combination of atmospheric inputs, biological production and photochemical processes (see above) might explain this high value.

\subsubsection{Intermediate depths (between the SML and $1500 \mathrm{~m}$ )}

In the STZ (stations L1, S1, L2, and S2), large sub-surface maxima of labile $\mathrm{Fe}$ (II) centered at $200-300 \mathrm{~m}$ were observed. Concentrations started to increase just at or below the maximum of chlorophyll-a (Ras and Clautres, personal communication, 2011) and high values were observed as deep as $700 \mathrm{~m}(0.09 \mathrm{nM}$, station $\mathrm{S} 1)$. Although generally lower than in the STZ (0.076-0.125 nM), sub-surface maxima were also observed in the ACC (0.023-0.087 nM) and north of the Weddell Gyre $(0.025 \mathrm{nM})$ at depth between 60 and $300 \mathrm{~m}$. As discussed above, due to the relatively long transport time between the African continental margin and the stations in the STZ, an input of Fe(II) from water masses enriched by the African continental margin is unlikely, unless organic complexation stabilized Fe(II) (Roy et al., 2008). Observed trends in labile $\mathrm{Fe}(\mathrm{II})$ compare well with depth profiles of dissolved $\mathrm{Mn}$ in the same sector of the Southern Ocean during the ANT XXIV/3 expedition (Middag et al., 2011). Subsurface maxima of Mn were identified at depths of around $150 \mathrm{~m}$ and coincided with a gradient in the potential density anomaly $\left(\sigma_{\theta}\right)$. A similar relationship was observed for the ${ }^{234} \mathrm{Th} /{ }^{238} \mathrm{U}$ ratio in the subsurface, with a steep increase towards values near or over 1 at the pycnocline (Rutgers van der Loeff. et al., 2011). This trend in ${ }^{234} \mathrm{Th} /{ }^{238} \mathrm{U}$ ratio indicates small scale remineralisation of sinking material (Cai et al., 2008, Maiti et al., 2010). During the BGH cruise, high resolution depth profiles were also obtained for ${ }^{234} \mathrm{Th} / 238 \mathrm{U}$ ratio and a more detailed data set will be available from the surface to $1000 \mathrm{~m}$ depth (Planchon et al., 2011). Except at station L6, our labile Fe(II) maxima also coincided with increases in ${ }^{234} \mathrm{Th} /{ }^{238} \mathrm{U}$ ratios in the subsurface (Fig. 7). ${ }^{234} \mathrm{Th} /{ }^{238} \mathrm{U}$ ratios ranging from 1 to maximum 1.3 clearly indicated fast and intense remineralization of sinking material in the mesopelagic zone $(100-600 \mathrm{~m})$, which was further confirmed by parallel biogenic particulate barium data (Baxs, Fig. 7, Planchon et al., 2011). Baxs is believed to represent a sensitive tracer of organic matter breakdown in the mesopelagic zone, since the breakdown of aggregates releases barite crystals and maintains a Baxs maximum occurring generally in the 100-600 m depth region (Dehairs et al., 1992). Therefore, a likely source of labile Fe(II) in the subsurface might be remineralization/disaggregation of biogenic particles settling from above. Moreover, the very large subsurface maxima in the STZ were consistent with a bloom in a senescent stage (Ras and Claustre, personal communication, 2011). The value of $\% \mathrm{Fe}(\mathrm{II}) / \mathrm{DFe}$ at these depths can be as high as $50-70 \%$, suggesting that biogenic $\mathrm{Fe}$ is mainly regenerated as $\mathrm{Fe}$ (II) species, as already observed in other studies (Hutchins and Bruland, 1994; Sarthou et al., 2008).

In the southern part of our transect (stations L6, S4, L7, S5, Fig. 8), the winter waters were strongly visible on the $T$ data and were associated with local minima of labile $\mathrm{Fe}(\mathrm{II})$ concentrations. Although the formation of the winter waters is on a seasonal time-scale and labile Fe(II) is a transient element, biological activity is lower in the winter water and the lower concentrations of labile $\mathrm{Fe}(\mathrm{II})$ in these water masses may reflect processes involving a biological source of $\mathrm{Fe}$ (II) in the surface waters and confirm results observed in the SML.

\subsubsection{Below $1500 \mathrm{~m}$}

Only two stations showed labile Fe(II) concentrations higher than the detection limit below $1500 \mathrm{~m}$. Station S2 was located at the vicinity of the Agulhas Ridge and local maxima of DFe were observed there (Chever et al., 2010), suggesting hydrothermal or sediment inputs (Elrod et al., 2004; Boyle and Jenkins, 2008; Bennett et al., 2008; Tagliabue et al., 


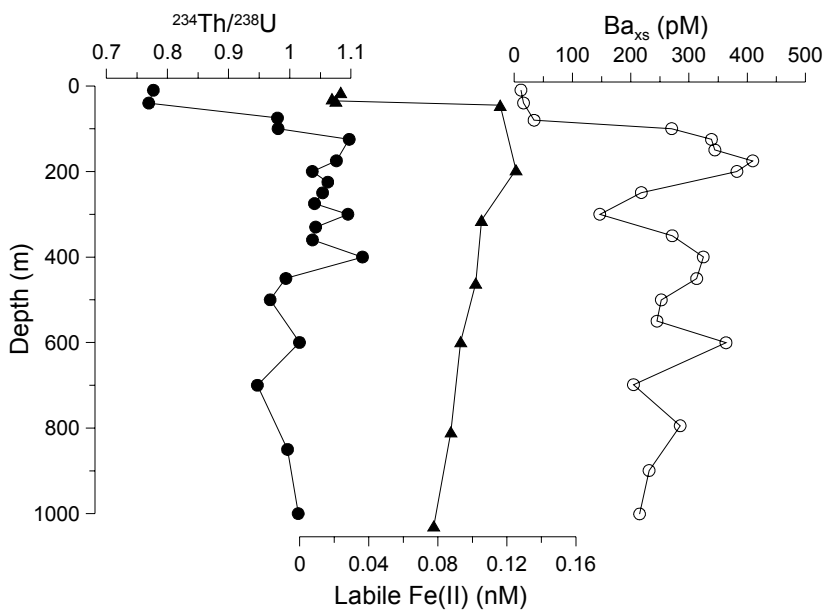

Fig. 7. Vertical profiles of ${ }^{234} \mathrm{Th} /{ }^{238} \mathrm{U}$, labile Fe(II) and Baxs at station S2. Baxs is the biogenic particulate Ba calculated by subtracting the lithogenic $\mathrm{Ba}$ from total particulate $\mathrm{Ba}$.

2010). $\% \mathrm{Fe}(\mathrm{II}) / \mathrm{DFe}$ was not very high (1.4-5\%) and Fe(II) half-life was the lowest of the section (Fig. 3b), suggesting that $\mathrm{Fe}$ (II) is continuously provided to the deep waters but reoxidized quite fast. During the ANT XXIV/3 expedition, Klunder et al. (2011) and Middag et al. (2011) evidenced hydrothermal inputs of $\mathrm{Fe}$ and $\mathrm{Mn}$ in the Bouvet region (52$56^{\circ} \mathrm{S}$ ). The hydrothermal signal was not clearly seen on our DFe (Chever et al., 2010) nor on our labile Fe(II) data, likely due to a lower resolution of our sampling. At station S5, concentrations of labile $\mathrm{Fe}(\mathrm{II})$ as high as $0.050 \mathrm{nM}$ were observed at $3500 \mathrm{~m}$, with $\% \mathrm{Fe}(\mathrm{II}) / \mathrm{DFe}$ equal to $13 \%$. Along the zero meridian, DFe concentrations in the deep waters north of the Weddell Gyre $(0.47 \pm 0.16 \mathrm{nM}, n=98$, Klunder et al., 2010, and $0.42 \pm 0.07, n=4$, Chever et al., 2010) were higher than south of the Weddell Gyre $(0.33 \pm 0.14 \mathrm{nM}$, $n=98$, Klunder et al., 2010). North of the Weddell Sea Gyre, the deep waters flow eastward, and might have had a recent contact with the northern limit of the Weddell Basin (Orsi et al., 1993; Meredith et al., 2000; Klatt et al., 2005), flowing along the North Weddell Ridge. A local reductive dissolution of particles coming from the slope sediments of the ridge may explain the high values of labile $\mathrm{Fe}(\mathrm{II})$ at this station.

\subsubsection{Oxidation rates}

The Fe(II) half-life values in the surface waters were similar to previous values estimated in natural surface seawater at near-ambient concentrations (6-28 min, Croot et al., 2008). Our values were higher in the deep than in the surface waters. To our knowledge, our study is the first to measure Fe(II) oxidation rates in natural deep seawater at near-ambient concentrations. The deep values were never as high as the ones estimated by Hansard et al. (2009, up to $690 \mathrm{~min}$ ) in the Pacific Ocean. However, their $\left[\mathrm{O}_{2}\right]$ at $\sim 1000 \mathrm{~m}$ were as low as $13 \mu \mathrm{M}$, whereas $\left[\mathrm{O}_{2}\right]$ was never lower than $100 \mu \mathrm{M}$ along
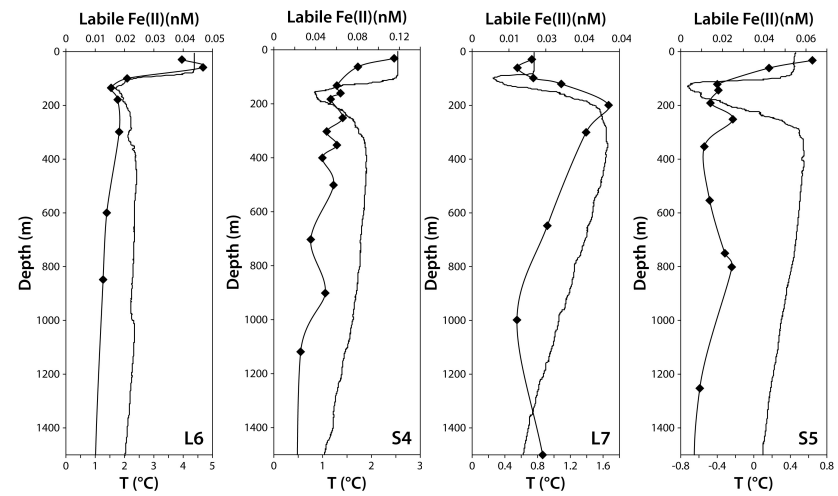

Fig. 8. Vertical profiles in the upper $1500 \mathrm{~m}$ of labile $\mathrm{Fe}(\mathrm{II})$ and $T$ at the 4 stations south of the PF where the AAWW were clearly seen.

the BGH transect. The overall oxidation rate of $\mathrm{Fe}(\mathrm{II})$ is a function of oxidant concentrations (e.g. oxygen, hydrogen peroxide, superoxide, etc., González-Dávila et al., 2006), $T, \mathrm{pH}$, as well as $\mathrm{Fe}(\mathrm{II})$ chemical speciation (mainly $\mathrm{Fe}^{2+}$, $\mathrm{Fe}(\mathrm{OH})^{+}, \mathrm{Fe}(\mathrm{OH})_{2}, \mathrm{FeCO}_{3}, \mathrm{Fe}\left(\mathrm{CO}_{3}\right)_{2}^{2-}, \mathrm{Fe}\left(\mathrm{CO}_{3}\right)(\mathrm{OH})^{-}$, Millero, 1989; King, 1998; Santana-Casiano et al., 2006; Trapp and Millero, 2007). To compare our data with theoretical ones, we used two published models of Fe(II) oxidation kinetics and in situ physical-chemical conditions (Model I: Santana-Casiano et al., 2005; Model II: Trapp and Millero, 2007; see Supplement for detailed calculations). Theoretical values are given in Table 3 . The two models differ in the equations used for the calculations of the oxidation rate constants of the individual species for oxidation by oxygen (see Supplement). Moreover, Model I considers the $\mathrm{Fe}\left(\mathrm{CO}_{3}\right)(\mathrm{OH})^{-}$species, as well as the oxidation by the superoxide. None of the two models considers organic matter effects, and differences in oxidation rates among samples are only related to $T, \mathrm{pH}, S$, and carbonate effects.

In the upper waters, for Model I, the Fe(II) half-life times ranged from 7.5 to $18.4 \mathrm{~min}$, with a mean value of $12.4 \pm 3.0 \mathrm{~min}$. For Model II, values ranged from 5.5 to $13.6 \mathrm{~min}$, with a mean value of $9.5 \pm 2.3 \mathrm{~min}$. The ranges of variations of the two theoretical data sets were similar, although a paired-t test showed that the two data sets were significantly different $(P<0.01, n=12)$, with values from Model I always higher than values from Model II (up to $5 \mathrm{~min}$ ). The measured $t_{1 / 2}(2.9-11.3 \mathrm{~min}$, mean value $6.7 \pm 2.6 \mathrm{~min}$ ) showed systematically lower values than the theoretical ones of both models (by up to $10-15 \mathrm{~min}$ at station L2), except at station S5 where the measured value was slightly higher than the Model II one. A much larger difference was observed in the deep waters between the two models. The Model I values ranged from 86 to $138 \mathrm{~min}$ (mean value $112 \pm 19 \mathrm{~min}$ ), whereas the Model II ones were about 4 times lower, ranging from 19 to $32 \mathrm{~min}$ (mean value $26 \pm 5 \mathrm{~min}$ ). This difference may come from the uncertainties in the model parameterization and/or on superoxide 
concentrations which could vary at depth more than oxygen concentration (see Supplement). However, what both models indicated was that in the deep waters, the half life times were almost constant (less than a factor of two) compared to the measured values which varied by a factor of 7 (10$72 \mathrm{~min}$ ). Indeed, in the deep waters, the $\mathrm{pH}$ and $T$ ranges of variation are relatively small, inducing a small range of variation of theoretical values. The largest range of variation of the measured values could be induced by a change in oxygen concentrations. Indeed, oxygen may have been consumed by micro-organisms in the sample during the $24 \mathrm{~h}$ storage or increase if an oxygen contamination occurred. Also, when the oxidation rates were measured at $4{ }^{\circ} \mathrm{C}$, the deep samples and some of the surface samples were heated while most of the surface samples were cooled. These differences can affect the intermediate species and equilibrium processes. Moreover, after heating, changes in $\mathrm{pH}$ due to $\mathrm{CO}_{2}$ dissolutionexchange can modify the Fe(II) speciation.

Another explanation for the variability of the measured $t_{1 / 2}$ and the discrepancy between measured and theoretical is organic complexation. Although dissolved $\mathrm{Fe}(\mathrm{III})$ is now well known to be strongly bound by organic chelators in seawater (Gledhill and van den Berg, 1994; Rue and Bruland, 1997; Gerringa et al., 2006, 2008; Thuróczy et al., 2010), organic complexation of Fe(II) has been suggested but never directly measured (Croot et al., 2007, 2008; Roy et al., 2008). In the Subarctic Pacific, Roy et al. (2008) observed a significant difference between the measured $\mathrm{Fe}$ (II) oxidation rates in natural surface water and the ones in UV-treated surface water, which strongly suggested that organic ligands influenced Fe(II) speciation in seawater. As for Fe(III) species, the Fe(II) organic speciation may help to maintain Fe(II) in the dissolved phase. However, numerous studies on the effect of Fe organic complexation on the oxidation kinetics have showed that organic complexation can either increase or decrease the $\mathrm{Fe}$ (II) oxidation rates (Rijkenberg et al., 2006 and references herein). Variability of organic compounds within the water column could thus induce variability in the observed oxidation rates.

\section{Conclusions}

Concentrations of labile $\mathrm{Fe}$ (II) in the surface waters were systematically higher than the detection limit of our analytical method. The highest values were observed where sampling was done between 12:00 and 16:00, suggesting a biological production of $\mathrm{Fe}(\mathrm{II})$ in the SML linked to photosynthesis. South of the section, local minima coinciding with the Winter Waters confirm that direct biological reduction of Fe(III) may occur in the SML. This would explain why our nighttime surface samples have concentrations higher than the detection limit. At intermediate depths, sub-surface maxima were observed all along the section, although more pronounced in the STZ. A bloom at a senescent stage in the STZ, together with a good consistency between the maxima of labile $\mathrm{Fe}(\mathrm{II})$ and the increase in ${ }^{234} \mathrm{Th} /{ }^{238} \mathrm{U}$ towards values over 1 suggested that $\mathrm{Fe}$ remineralization occurred at those depths and that Fe was mainly regenerated as $\mathrm{Fe}$ (II) species. In the deep waters, labile Fe(II) concentrations were higher than the detection limit at two stations: one located at the vicinity of the Agulhas ridge and another one in the north of the Weddell Gyre. Here we propose that this was likely due to hydrothermal and/or sediment inputs. Fe(II) oxidation rates were measured in the surface and deep waters. Our study is the first one, to our knowledge, to measure $\mathrm{Fe}$ (II) oxidation rates in natural deep seawater at near-ambient concentrations. In the deep waters, $t_{1 / 2}$ values were on average 6 times higher than in the surface waters. The comparison of our measured $t_{1 / 2}$ with theoretical ones using two different models suggested that organic complexation may strongly influence the oxidation rates, although more studies are needed to better constrain the organic speciation of $\mathrm{Fe}(\mathrm{II})$ and its influence on the half-lives of $\mathrm{Fe}(\mathrm{II})$. The global data set of $\mathrm{Fe}(\mathrm{II})$ also needs to be increased and this will be done in the framework of the GEOTRACES programme and the associated cruises.

\section{Supplementary material related to this article is available online at: http://www.biogeosciences.net/8/2461/2011/ bg-8-2461-2011-supplement.pdf.}

Acknowledgements. We are grateful to Frank Dehairs, the cochief scientist with S.S., the captain and the crew of the R/V Marion Dufresne for their excellent support and commitment onboard. This work was supported by the Institut National des Sciences de L'Univers of the Centre National de la Recherche Scientifique, the French Polar Institute (Institut Polaire Emile Victor), the French Research Institute for Exploitation of the Sea, and the National Agency for Research Funding (ANR-07-BLAN-0146). We thank Josephine Ras and Hervé Claustre for providing pigment data, Damien Cardinal for barium data, and Erika Key for the solar radiation data. Mikael Trapp is also thanked for his help with the $\mathrm{Fe}$ (II) oxidation model. We also acknowledge the Go-Flo sampling team: J. Bown, M. Boyé, F. Lacan, A. Radic, and B. Wake.

Edited by: K. Suzuki

\section{References}

Alldredge, A. L. and Cohen, Y.: Can microscale patches persist in the sea? Microelectrode study of marine snow, feacal pellets, Science, 235, 689-601, 1987.

Arhan, M., Mercier, H., and Park, Y.: On the deep water circulation of the eastern South Atlantic Ocean, Deep Sea Res. Pt. I, 50(7), 889-916, 2003.

Arhan, M., Speich, S., Dencausse, G., Messager, C., Fine, R. and Boye, M.: Anticyclonic and cyclonic eddies of subtropical origin in the subantarctic zone south of Africa, J. Geophys. Res.: Oceans, submitted, 2011. 
Barbeau, K., Rue, E. L., Bruland, K. W., and Butler, A.: Photochemical cycling of iron in the surface ocean mediated by microbial iron(III)-binding ligands, Nature, 413, 409-413, 2001.

Bennett, S. A., Achterberg, E. P., Connelly, D. P., Statham, P. J., Fones, G. R., and German, C. R.: The distribution and stabilisation of dissolved Fe in deep-sea hydrothermal plumes, Earth Planet. Sci. Lett., 270(3-4), 157-167, 2008.

Blain, S., Quéguiner, B., Armand, L., Belviso, S., Bombled, B., Bopp, L., Bowie, A., Brunet, C., Brussaard, C., Carlotti, F., Christaki, U., Corbière, A., Durand, I., Ebersbach, F., Fuda, J.L., Garcia, N., Gerringa, L., Griffiths, B., Guigue, C., Guillerm, C., Jacquet, S., Jeandel, C., Laan, P., Lefèvre, D., Lomonaco, C., Malits, A., Mosseri, J., Obernosterer, I., Park, Y.-H., Picheral, M., Pondaven, P., Remenyi, T., Sandroni, V., Sarthou, G., Savoye, N., Scouarnec, L., Souhaut, M., Thuiller, D., Timmermans, K., Trull, T., Uitz, J., van-Beek, P., Veldhuis, M., Vincent, D., Viollier, E., Vong, L., and Wagener, T.: Impact of natural iron fertilization on carbon sequestration in the Southern Ocean, Nature, 7139, 1070-1074, 2007.

Boebel, O., Lutjeharms, J., Schmid, C., Zenk, W., Rossby, T. and Barron, C.: The Cape Cauldron: a regime of turbulent interocean exchange, Deep-Sea Res. Pt. II, 50, 57-86, 2003.

Bowie, A. R., Achterberg, E. P., Sedwick, P. N., Ussher, S., and Worsfold, P. J.: Real-time monitoring of picomolar concentrations of iron(II) in marine waters using automated flow injection chemiluninescence instrumentation, Environ. Sci. Technol., 36, 4600-4607, 2002.

Boyd, P. W.: Ironing out algal issues in the southern ocean, Science, 304(5669), 396-397, 2004.

Boyd, P. W. and Ellwood, M. J.: The biogeochemical cycle of iron in the ocean, Nat. Geosci., 3, 675-682, doi:10.1038/NGEO964, 2010.

Boyd, P. W., Watson, A. J., Law, C. S., Abraham, E. R., Trull, T., Murdoch, R., Bakker, D. C. E., Bowie, A., Buesseler, K. O., Chang, H., Charette, M., Croot, P., Downing, K., Frew, R., Gall, M., Hadfield, M., Hall, J., Harvey, M., Jameson, G., LaRoche, J., Liddicoat, M., Ling, R., Maldonado, M.T., McKay, R.M., Nodder, S., Pickmere, S., Pridmore, R., Rintoul, S., Safi, K., Sutton, P., Strzepek, R., Tanneberger, K., Turner, S., Waite, A., and Zeldis, J.: A mesoscale phytoplankton bloom in the polar Southern Ocean stimulated by iron fertilization, Nature, 407, 695-702, 2000.

Boye, M., Aldrich, A., van den Berg, C. M. G., de Jong, J. T. M., Veldhuis, M., and de Baar, H. J. W.: Horizontal gradient of the chemical speciation of iron in surface waters of the northeast Atlantic Ocean, Mar. Chem., 80, 129-143, 2003.

Boye, M., Aldrich, A., van den Berg, C. M. G., de Jong, J. T. M., Nirmaier, H., Veldhuis, M., Timmermans, K. R., and de Baar, H. J. W.: The chemical speciation of iron in the north-east Atlantic Ocean, Deep Sea Res. Pt. I, 53, 667-683, 2006.

Boyle, E. and Jenkins, W.: Hydrothermal Iron in the Deep Western South Pacific, Geochim. Cosmochim. Ac., 72(12, Supplement 1), A107, 2008.

Bruland, K. W. and Rue, E. L.: Analytical Methods for the Determination of Concentrations and Speciation of Iron, edited by: Turner, S. and Hunter, K. A., Biogeochemistry of Fe in Seawater, SCOR/IUPAC, 255-290, 2001.

Bucciarelli, E., Sarthou, G., and Chever, F.: Hydrogen peroxide distributions along a transect from the subtropical domain to the
Weddell Sea Gyre in the Atlantic sector of the Southern Ocean, in prep., 2011.

Cai, P. H., Chen, W. F., Dai, M. H., Wan, Z. W., Wang, D. X., Li, Q., Tang, T. T., and Lv, D. W.: A high resolution study of particle export in the southern South China Sea based on ${ }^{234} \mathrm{Th}:{ }^{238} \mathrm{U}$ disequilibrium, J. Geophys. Res. Oceans, 113(C4), C04019, doi:10.1029/2007JC004268, 2008.

Chever, F., Bucciarelli, E., Sarthou, G., Speich, S., Arhan, M., Penven, P., and Tagliabue, A.: Physical speciation of iron in the Atlantic sector of the Southern Ocean, along a transect from the subtropical domain to the Weddell Sea Gyre, J. Geophys. Res. Ocean, 115, C10059, doi:10.1029/2009JC005880, 2010.

Chin, C. S., Coale, K. H., Elrod, V. A., and Johnson, K. S.: In situ observations of dissolved iron and manganese in hydrothermal vent plumes, Juan de Fuca Ridge, J. Geophys. Res., 99(B3), 4969-4984, 1994.

Coale, K. H., Chin, C. S., Massoth, G. J., Johnson, K. S., and Baker, E. T.: in situ chemical mapping of dissolved iron and manganese in hydrothermal plumes, Nature, 352, 325-328, 1991.

Coale, K. H., Johnson, K. S., Fitzwater, S. E., Gordon, R. M., Tanner, S., Chavez, F. P., Ferioli, L., Sakamoto, C., Rogers, P., Millero, F., Steinberg, P., Nightingale, P., Cooper, D., Cochlan, W. P., Landry, M. R., Constantinou, J., Rollwagen, G., Trasvina, A., and Kudela, R.: A massive phytoplankton bloom induced by an ecosystem-scale iron fertilization experiment in the equatorial Pacific Ocean, Nature, 383, 495-501, 1996.

Coale, K. H., Johnson, K. S., Chavez, F. P., Buesseler, K. O., Barber, R. T., Brzezinski, M. A., Cochlan, W. P., Millero, F. J., Falkowski, P. G., Bauer, J. E., Wanninkhof, R. H., Kudela, R. M., Altabet, M. A., Hales, B. E., Takahashi, T., Landry, M. R., Bidigare, R. R., Wang, X. J., Chase, Z., Strutton, P. G., Friederich, G. E., Gorbunov, M. Y., Lance, V. P., Hilting, A. K., Hiscock, M. R., Demarest, M., Hiscock, W. T., Sullivan, K. F., Tanner, S. J., Gordon, R. M., Hunter, C. N., Elrod, V. A., Fitzwater, S.E., Jones, J. L., Tozzi, S., Koblizek, M., Roberts, A. E., Herndon, J., Brewster, J., Ladizinsky, N., Smith, G., Cooper, D., Timothy, D., Brown, S. L., Selph, K. E., Sheridan, C. C., Twining, B. S., and Johnson, Z. I.: Southern ocean iron enrichment experiment: Carbon cycling in high- and low-Si waters, Science, 304(5669), 408-414, 2004.

Croot, P. L. and Laan, P.: Continuous shipboard determination of $\mathrm{Fe}(\mathrm{II})$ in polar waters using flow injection analysis with chemiluminescence detection, Anal. Chim. Acta, 466(2), 261-273, 2002.

Croot, P. L., Bowie, A. R., Frew, R. D., Maldonado, M. T., Hall, J. A., Safi, K. A., La Roche, J., Boyd, P. W., and Law, C. S.: Retention of dissolved iron and Fe-II in an iron induced Southern Ocean phytoplankton bloom, Geophys. Res. Lett., 28(18), 34253428, 2001.

Croot, P. L., Laan, P., Nishioka, J., Strass, V., Cisewski, B., Boye, M., Timmermans, K. R., Bellerby, R. G., Goldson, L., Nightingale, P., and de Baar, H. J. W.: Spatial and temporal distribution of $\mathrm{Fe}(\mathrm{II})$ and $\mathrm{H}_{2} \mathrm{O}_{2}$ during EisenEx, an open ocean mescoscale iron enrichment, Mar. Chem., 95, 65-88, 2005.

Croot, P. L., Frew, R. D., Sander, S., Hunter, K. A., Ellwood, M. J., Pickmere, S. E., Abraham, E. R., Law, C. S., Smith, M. J., and Boyd, P. W.: Physical mixing effects on iron biogeochemical cycling: Fe-Cycle experiment, J. Geophys. Res., 112(C06015), doi:10.1029/2006JC003748, 2007.

Croot, P. L., Bluhm, K., Schlosser, C., Streu, P., Breitbarth, E., 
Frew, R. and Ardelan, M. V.: Regeneration of Fe(II) during EIFeX and SOFeX, Geophys. Res. Lett., 35, L19606, doi:10.1029/2008GL035063, 2008.

de Baar, H. J. W. and de Jong, J. T. M.: Distributions, Sources and Sinks of Iron in Seawater, edited by:: Turner, D. R. and Hunter, K. A., Biogeochemistry of Fe in Seawater. SCOR-IUPAC series, J Wiley, Baltimore, 123-253, 2001.

Dehairs, F., Baeyens, W., and Goeyens, L.: Accumulation of suspended barite at mesopelagic depths and export production in the Southern Ocean, Science, 258, 1332-1335, 1992.

Ducet, N., Traon, P. Y. L., and Reverdin, G.: Global high-resolution mapping of ocean circulation from TOPEX/Poseidon and ERS-1 and -2, J. Geophys. Res., 105(C8), 19477-19498, 2000.

Elrod, V. A., Berelson, W. M., Coale, K. H., and Johnson, K. S.: The flux of iron from continental shelf sediments: A missing source for global budgets, Geophys. Res. Lett., 31, L12307, doi:10.1029/2004GL020216, 2004.

Field, M. P. and Sherrell, R. M.: Dissolved and particulate Fe in a hydrothermal plume at $9^{\circ} 45^{\prime} \mathrm{N}$, East Pacific Rise: Slow Fe (II) oxidation kinetics in Pacific plumes, Geochim. Cosmochim. Ac., 64(4), 619-628, 2000.

Gerringa, L. J. A., Veldhuis, M. J. W., Timmermans, K. R., Sarthou, G., and de Baar, H. J. W.: Co-variance of dissolved Fe-binding ligands with biological observations in the Canary Basin., Mar. Chem., 102, 276-290, 2006.

Gerringa, L. J. A., Blain, S., Laan, P., Sarthou, G., Veldhuis, M. J. W., Viollier, E., and Timmermans, K. R.: Dissolved organic ligands of $\mathrm{Fe}$ near the Kerguelen Archipelago in the Southern Ocean (Indian sector), Deep Sea Res. Pt. II, 55(5-7), 606-621, 2008.

Gervais, F., Riebesell, U., and Gorbunov, M. Y.: Changes in primary productivity and chlorophyll a in response to iron fertilization in the Southern Polar Frontal Zone, Limnol. Oceanogr., 47(5), 1324-1335, 2002.

Gladyshev, S., Arhan, M., Sokov, A., and Speich, S.: A hydrographic section from South Africa to the southern limit of the Antarctic Circumpolar Current at the Greenwich meridian, Deep Sea Res. Pt. I, 55, 1284-1303, 2008.

Gledhill, M. and van den Berg, C. M. G.: Determination of complexation of iron(III) with natural organic complexing ligands in seawater using cathodic stripping voltammetry, Mar. Chem., 47, 41-54, 1994.

Gledhill, M. and van den Berg, C. M. G.: Measurement of the redox speciation of iron in seawater by catalytic cathodic stripping voltammetry, Mar. Chem., 50(1-4), 51-62, 1995.

Gobler, C. J., Donat, J. R., Consolvo, J. A., and Sanudo, W. S. A.: Physicochemical speciation of iron during coastal algal blooms, Mar. Chem., 77(1), 71-89, 2002.

Godrant, A., Rose, A. L., Sarthou, G., and Waite, T. D.: A new method for the determination of extracellular production of superoxide from phytoplankton cells using the chemiluminescence probes MCLA and the Red-CLA, Limnol. Oceanogr. Meth., 7, 682-692, 2009.

González-Dávila, M., Santana-Casiano, J. M., Rueda, M. J., Llinás, O., and Gonzalez-Dávila, E. F.: Seasonal and interannual variability of seasurface carbon dioxide species at the European Station for Time Series in the Ocean at the Canary Islands (ESTOC) between 1996 and 2000, Global Biogeochem. Cy., 17(3), 1076, doi:10.1029/2002GB001993, 2003.
González-Dávila, M., Santana-Casiano, J. M., and Millero, F. J.: Oxidation of iron (II) nanomolar with $\mathrm{H}_{2} \mathrm{O}_{2}$ in seawater, Geochim. Cosmochim. Ac., 69, 83-93, 2005.

González-Dávila, M., Santana-Casiano, J. M., and Millero, F. J.: Competition between $\mathrm{O}_{2}$ and $\mathrm{H}_{2} \mathrm{O}_{2}$ in the oxidation of $\mathrm{Fe}(\mathrm{II})$ in natural waters, J. Sol. Chem., 35, 95-111, 2006.

Gordon, A. L., Weiss, R. F., Smethie, J. W. M., and Warner, M. J.: Thermocline and intermediate water communication between the South Atlanctic and Indian Oceans, J. Geophys. Res., 97(C5), 7223-7240, 1992.

Hansard, S. P., Landing, W. M., Measures, C. I., and Voelker, B. M.: Dissolved iron(II) in the Pacific Ocean: Measurements from the $\mathrm{PO}_{2}$ and $\mathrm{P} 16 \mathrm{NCLIVAR} / \mathrm{CO}_{2}$ repeat hydrography expeditions, Deep Sea Res. Pt. I, 56, 1117-1129, 2009.

Hansard, S.P., Vermilyea, A.W. and Voelker, B.M.: Measurements of superoxide radical concentration and decay kinetics in the Gulf ofAlaska, Deep-Sea Res. I, 57, 1111-1119, 2010.

Hong, H. and Kester, D. R.: Redox state of iron in the offshore waters of Peru, Limnol. Oceanogr., 31, 512-524, 1986.

Hopkison, B. M. and Barbeau, K. A.: Organic and Redox speciation of iron in the tropical North Pacific suboxic zone, Mar. Chem., 106, 2-17, 2007.

Hutchins, D. A. and Bruland, K. W.: Grazer-mediated regeneration and assimilation of $\mathrm{Fe}, \mathrm{Zn}$, and $\mathrm{Mn}$ from planktonic prey, Mar. Ecol. Prog. Ser., 110, 259-269, 1994.

Hutchins, D. A., DiTullio, G. R., and Bruland, K. W.: Iron and regenerated production: Evidence for biological iron recycling in two marine environments, Limnol. Oceanogr., 38(6), 12421255, 1993.

Hutchins, D. A., Wang, W., and Fisher, N. S.: Copepod grazing and the biogeochemical fate of diatom iron, Limnol. Oceanogr., 40, 989-994, 1995.

Johnson, K. S., Coale, K. H., Elrod, V. A. and Tindale, N. W.: Iron Photochemistry in seawater from the Equatorial Pacific, Mar. Chem., 46, 319-334, 1994.

Johnson, K. S., Gordon, R. M., and Coale, K. H.: What controls dissolved iron concentrations in the world ocean?, Mar. Chem., 57, 137-161, 1997.

Journet, E., Desboeufs, K. V., Sofikitis, A., Varrault, G., and Colin, J.-L.: In situ speciation of trace $\mathrm{Fe}(\mathrm{II})$ and $\mathrm{Fe}(\mathrm{III})$ in atmospheric waters by the FZ method coupled to GFAAS analysis, Intern. J. Environ. Anal. Chem., 87(9), 647-658, 2007.

Kieber, R. J., Williams, K., Willey, J. D., Skrabal, S., and Avery, G. B: Iron speciation in coastal rainwater: concentration and deposition to seawater, Mar. Chem., 73(2), 83-95, 2001.

King, D. W.: Role of carbonate speciation on the oxidation rate of $\mathrm{Fe}(\mathrm{II})$ in aquatic systems, Environ. Sci. Technol. , 32, 29973003, 1998.

King, D. W., Aldrich, R. A., and Charnecki, S. E.: Photochemical redox cycle of iron in $\mathrm{NaCl}$ solutions, Mar. Chem., 44, 105-120, 1993.

King, D. W., Lounsbury, H. A., and Millero, F. J.: Rate and mechanism of $\mathrm{Fe}$ (II) oxidation at nanomolar total iron concentration, Environ. Sci. Technol., 29(3), 818-824, 1995.

Klatt, O., Fahrbach, E., Hoppema, M., and Rohardt, G.: The transport of the Weddell Gyre across the Prime meridian, Deep Sea Res. Pt. II, 52, 513-528, doi:10.1016/j.dsr2.2004.12.015, 2005.

Klunder, M., Laan, P., Middag, R., de Baar, H. J. W., and van Ooijen, J. C.: Dissolved Iron the Southern Ocean (Atlantic Sector), 
Deep Sea Res. Pt. II, in press, doi:10.1016/j.dsr2.2010.10.042, 2011.

Kuma, K., Nakabayashi, S., Suzuki, Y., Kudo, I., and Matsunaga, K.: Photoreduction of $\mathrm{Fe}(\mathrm{III})$ by dissolved organic substances and existence of $\mathrm{Fe}(\mathrm{II})$ in seawater during spring blooms, Mar. Chem., 37, 15-27, 1992a.

Kuma, K., Nakabayashi, S., Suzuki, Y., and Matsunaga, K.: Dissolution rate and solubility of colloidal hydrous ferric oxide in seawater, Mar. Chem., 38, 133-143, 1992 b.

Kuma, K., Nishioka, J., and Matsunaga, K.: Controls on iron(III) hydroxide solubility in seawater: the influence of $\mathrm{pH}$ and natural organic ligands, Limnol. Oceanogr., 41(3), 396-407, 1996.

Kustka, A. B., Shaked, Y., Milligan, A. J., King, D. W., and Morel, F. M. M.: Extracellular production of superoxide by marine diatoms: Contrasting effects on iron redox chemistry and bioavailability, Limnol. Oceanogr., 50(4), 1172-1180, 2005.

Legendre, L., Demers, S., Garside, C., Haugen, E. M., Phinney, D. A., Shapiro, L. P., Therriault, J. C., and Yentsch, C. M.: Circadian photosynthetic activity of natural marine phytoplankton isolated in a tank, J. Plankton Res., 10, 1-6, 1988.

Lewis, E. and Wallace, D. W. R.: Program Developed for $\mathrm{CO}_{2}$ System Calculations. ORNL/CDIAC-105, Carbon Dioxide Information Analysis Center, Oak Ridge National Laboratory, U.S. Department of Energy, Oak Ridge, Tennessee, 1998.

Liu, X. and Millero, F. J.: The solubility of iron in seawater, Mar. Chem., 77(1), 43-54, 2002.

Lohan, M. C. and Bruland, K. W.: Elevated Fe(II) and dissolved $\mathrm{Fe}$ in hypoxic shelf waters off Oregon and Washington: An enhanced source of iron to coastal upwelling regimes, Environ. Sci. Technol., 42(17), 6462-6468, 2008.

Maiti, K., Benitez-Nelson, C. R. and Buesseler, K. O.: Insights into particle formation and remineralization using the short-lived radionuclide, Thoruim-234, Geophys. Res. Lett., 37, L15608, doi:10.1029/2010GL044063, 2010.

Maldonado, M. T. and Price, N. M.: Utilization of iron bound to strong organic ligands by plankton communities in the subarctic Pacific Ocean, Deep Sea Res. Pt. II, 46(11-12), 2447-2473, 1999.

Maldonado, M. T. and Price, N. M.: Reduction and transport of organically bound iron by Thalassiosira oceanica (Bacillariophyceae), J. Phycol., 37(2), 298-309, 2001.

Maldonado, M. T., Allen, A. E., Chong, J. S., Lin, K., Leus, D., Karpenko, N., and Harris, S. L.: Copper-dependent iron transport in coastal and oceanic diatoms, Limnol. Oceanogr. , 51(4), 17291743, 2006.

Meredith, M. P., Locarnini, R. A., Scoy, K. A. V., Watson, A. J., Heywood, K. J., and King, B. A.: On the sources of Weddell Gyre Antarctic Bottom Water, J. Geophys. Res., 105(C1), 10931104, 2000.

Middag, R., de Baar, H. J. W., Laan, P., Cai, P. H., and van Ooijen, J. C.: Dissolved manganese in the atlantic sector of the Southern Ocean, Deep Sea Res. Pt. II, in press, doi:10.1016/j.dsr2.2010.10.043, 2011.

Millero, F. J.: Effect of ionic interactions on the oxidation of iron(II) and copper(I) in natural waters, Mar. Chem., 28, 1-18, 1989.

Millero, F. J.: Thermodynamics of the carbon dioxide system in the oceans, Geochim. Cosmochim. Ac., 59, 661-677, 1995.

Millero, F. J. and Sotolongo, S.: The oxidation of $\mathrm{Fe}(\mathrm{II})$ with $\mathrm{H}_{2} \mathrm{O}_{2}$ in seawater, Geochim. Cosmochim. Ac., 53, 1867-1873, 1989.
Millero, F. J., Sotolongo, S., and Izaguirre, M.: The oxidation kinetics of Fe(II) in seawater, Geochim. Cosmochim. Ac., 51, 793 801, 1987.

Mintrop, L., Pérez, F. F., González Dávila, M., Körtzinger, A., and Santana-Casiano, J. M.: Alkalinity determination by potentiometry: intercalibration using three different methods, Cien. Mar., 26, 23-37, 2000.

Moffett, J., Goepfert, T. J., and Naqvi, W. A.: Reduced iron associated with secondary nitrite maxima in the Arabian Sea, Deep Sea Res. Pt. I, 54, 1341-1349, 2007.

Morel, F. M. M., Kustka, A. B., and Shaked, Y.: The role of unchelated $\mathrm{Fe}$ in the iron nutrition of phytoplankton, Limnol. Oceanogr., 53(1), 400-404, 2008.

O’Sullivan, D. W., Hanson, A. K., Miller, W. L., and Kester, D. R.: Measurement of Fe(II) in equatorial Pacific surface seawater, Limnol. Oceanogr., 36(8), 1727-1741, 1991.

Obata, H., Karatani, H., and Nakayama, E.: Automated determination of iron in seawater by chelating resin concentration and chemiluminescence, Anal. Chem., 65, 1524-1528, 1993.

Orsi, A. H., Nowlin, W. D., and Whitworth III, T.: On the circulation and stratification of the Weddell Gyre, Deep Sea Res. Pt. I, 40, 169-203, 1993.

Ozsoy, T. and Saydam, A. C.: Iron speciation in precipitation in the north-eastern Mediterranean and its relationship with Sahara dust, J. Atmos. Chem., 40, 41-76, 2001.

Planchon, F., Cavagna, A. J., Cardinal, D., André, L., and Dehairs, F.: Dynamics of biogenic particles in the Southern Ocean as revealed by ${ }^{234} \mathrm{Th}$ activity, POC and biogenic Ba along Greenwich Meridian, Biogeosciences, in prep., 2011.

Pollard, R., Sanders, R., Lucasa, M., and Statham, P.: The Crozet Natural Iron Bloom and Export Experiment (CROZEX), Deep Sea Res. Pt. II, 54(18-20), 1905-1914, 2007.

Rich, H. W. and Morel, F. M. M.: Availability of well-defined iron colloids to the marine diatom Thalassiosira weissflogii, Limnol. Oceanogr., 35(3), 652-662, 1990.

Rijkenberg, M. J. A., Gerringa, L. J. A., Carolus, V. E., Velzeboer, I., and de Baar, H. J. W.: Enhancement and inhibition of iron photoreduction by individual ligands in open ocean seawater, Geochim. Cosmochim. Ac., 70, 2790-2805, 2006.

Rose, A. L. and Waite, T. D.: Chemiluminescence of luminol in the persence of iron(II) and oxygen: Oxidation mechanism and implications for its analytical use, Anal. Chem., 73, 5909-5920, 2001.

Rose, A. L. and Waite, T. D.: Kinetic model for Fe(II) oxidation in seawater in the absence and presence of natural organic matter, Environ. Sci.Technol., 36, 433-444, 2002.

Rose, A. L. and Waite, T. D.: Predicting iron speciation in coastal waters from the kinetics of sunlight-mediated iron redox cycling, Aquat. Sci., 65, 375-383, 2003.

Rose, A. L., Salmon, T. P., Lukondeh, T., Neilan, B. A., and Waite, T. D.: Use of Superoxide as an Electron Shuttle for Iron Acquisition by the Marine Cyanobacterium Lyngbya majuscula, Environ. Sci. Tech., 39(10), 3708-3715, doi:10.1021/es048766c, 2005 .

Roy, E. G., Wells, M. L., and King, D. W.: Persistence of iron(II) in surface waters of the western subarctic Pacific, Limnol. Oceanogr., 53, 89-98, 2008.

Rue, E. L. and Bruland, K. W.: The role of organic complexation on ambient iron chemistry in the equatorial Pacific Ocean and 
the response of a mesoscale iron addition experiment, Limnol. Oceanogr., 42(5), 901-910, 1997.

Rutgers van der Loeff., M. M., Cai, P. H., Stimac, I., Bracher, A., Middag, R., Klunder, M. B., and Van Heuven, S.: ${ }^{234}$ Th in surface waters: distribution of particle export flux across the Antarctic Circumpolar Current and in the Weddell Sea during the GEOTRACES expedition ZERO and DRAKE, Deep-Sea Res. Pt. II, in press, doi:10.1016/j.dsr2.2011.02.004, 2011.

Salmon, T. P., Rose, A. L., Neilan, B. A., and Waite, T. D.: The FeL model of iron acquisition: Nondissociative reduction of ferric complexes in the marine environment, Limnol. Oceanogr., 51(4), 1744-1754, 2006.

Santana-Casiano, J. M., Gonzalez-Davila, M., and Millero, F. J.: The oxidation of $\mathrm{Fe}(\mathrm{II})$ in $\mathrm{NaCl}-\mathrm{HCO}_{3}^{-}$and seawater solutions in the presence of phthalate and salicylate ions: a kinetic model, Mar. Chem., 85(1-2), 27-40, 2004.

Santana-Casiano, J. M., Gonzalez-Davila, M., and Millero, F. J.: Oxidation of nanomolar levels of $\mathrm{Fe}(\mathrm{II})$ with oxygen in natural waters, Environ. Sci. Techn., 39, 2073-2079, 2005.

Santana-Casiano, J. M., Gonzalez-Davila, M., and Millero, F. J.: The role of $\mathrm{Fe}(\mathrm{II})$ species on the oxidation of $\mathrm{Fe}(\mathrm{II})$ in natural waters in the presence of $\mathrm{O}_{2}$ and $\mathrm{H}_{2} \mathrm{O}_{2}$, Mar. Chem., 99, 70-82, 2006.

Sarthou, G., Baker, A. R., Blain, S., Achterberg, E. P., Boye, M., Bowie, A. R., Croot, P. L., Laan, P., de Baar, H. J. W., Jickells, T. D., and Worsfold, P. J.: Atmospheric iron deposition and sea-surface dissolved iron concentrations in the eastern Atlantic Ocean, Deep Sea Res. Pt. I, 50(10-11), 1339-1352, 2003.

Sarthou, G., Vincent, D., Christaki, U., Obernosterer, I., Timmermans, K. R., and Brussaard, C. P. D.: The fate of biogenic iron during a phytoplankton bloom induced by natural fertilization: impact of copepod grazing, Deep Sea Res. Pt. II, 55, 734-751, 2008.

Shaked, Y., Kustka, A. B., Morel, F. M. M., and Erel, Y.: Simultaneous determination of iron reduction and uptake by phytoplankton, Limnol. Oceanogr. Meth., 2, 137-145, 2004.

Speich, S., Arhan, M., Gladyshev, S., Perrot, X., Fine, R., Boyé, M., and Delille, B.: Water masses and ocean dynamics south-west of Africa during the BONUS-GoodHope IPY transect, Ocean Science, in prep., 2011.

Statham, P. J., German, C. R., and Connelly, D. P.: Iron(II) distribution and oxidation kinetics in hydrothermal plumes at the Kairei and Edmond vent sites, Indian Ocean, Earth Planet. Sci. Lett., 236, 588-596, 2005.

Sunda, W. G.: Trace metal interactions with marine phytoplankton, Biol. Oceanogr., 6(5-6), 411-442, 1989.
Tagliabue, A., Bowie, A., Chever, F., Baptiste, P.-J., Dutay, J.-C., Bucciarelli, E., Lannuzel, D., Remenyi, T., Sarthou, G., Aumont, O., Gehlen, M. and Bopp, L.: On the importance of hydrothermalism to the oceanic dissolved iron inventory, Nat. Geosci., 3, 252-256, doi:10.1038/NGEO818, 2010.

Thuróczy, C.-E., Gerringa, L. J. A., Klunder, M. B., Middag, R., Laan, P., Timmermans, K. R., and de Baar, H. J. W.: Speciation of Fe in the Eastern North Atlantic Ocean, Deep Sea Res. Pt. I 57(11), 1444-1453, 2010.

Trapp, J. M. and Millero, F. J.: The oxidation of iron(II) with oxygen in $\mathrm{NaCl}$ brines, J. Sol. Chem., 36, 1479-1493, 2007.

Tsuda, A., Takeda, S., Saito, H., Nishioka, J., Nojiri, Y., Kudo, I., Kiyosawa, H., Shiomoto, A., Imai, K., Ono, T., Shimamoto, A., Tsumune, D., Yoshimura, T., Aono, T., Hinuma, A., Kinugasa, M., Suzuki, K., Sohrin, Y., Noiri, Y., Tani, H., Deguchi, Y., Tsurushima, N., Ogawa, H., Fukami, K., Kuma, K., and Saino, T.: A mesoscale iron enrichment in the western Subarctic Pacific induces a large centric diatom bloom, Science, 300, 958-961, 2003.

Ussher, S. J., Yaqoob, M., Achterberg, E. P., Nabi, A., and Worsfold, P. J.: Effect of model ligands on iron redox speciation in natural waters using flow injection with luminol chemiluminescence detection, Anal. Chem., 77(7), 1971-1978, 2005.

Ussher, S. J., Worsfold, P. J., Achterberg, E. P., Laes, A., Blain, S., Laan, P., and de Baar, H. J. W.: Distribution and redox speciation of dissolved iron on the European continental margin, Limnol. Oceanogr., 52(6), 2530-2539, 2007.

Voelker, B. M. and Sedlak, D. L.: Iron reduction by photoproduced superoxide in seawater, Mar. Chem., 50(1-4), 93-102, 1995.

Waite, T. D. and Morel, F. M. M.: Coulorimetric study of the redox dynamics of iron in seawater, Anal. Chem., 56, 787-792, 1984.

Waite, T. D., Szymczak, R., Espey, Q. I., and Furnas, M. J.: Diel variations in iron speciation in northern Australian shelf waters, Mar. Chem., 50(1-4), 79-92, 1995.

Wells, M. L., Mayer, L. M., Donard, O. F. X., de Souza Sierra, M. M., and Ackelson, S. G.: The photolysis of colloidal iron in the oceans, Nature, 353, 248-250, 1991.

Whitworth III, T. and Nowlin, J. W. D.: Water masses and currents of the Southern Ocean at the Greenwich Meridian, J. Geophys. Res., 96(C6), 6462-6476, 1987.

Windom, H. L., Moore, W. S., Niencheski, L. F. H., and Jahnke, R. A.: Submarine groundwater discharge: a large, previously unrecognized source of dissolved iron to the South Atlantic Ocean, Mar. Chem., 102, 252-266, 2006.

Yuan, J. and Shiller, A. M.: Determination of Subnanomolar Levels of Hydrogen Peroxide in Seawater by Reagent-Injection Chemiluminescence Detection, Anal. Chem., 71, 1975-1980, 1999. 